\title{
TAC MAHAL'İN HAT SÜSLEMELERİ İLE YAZITLARINDAKİ SURE VE AYETLER ÜZERİNE BİR DEĞERLENDİRME
}

\author{
(1) Fadime ÖZLER ${ }^{a}$
}

Öz

Dünya mimarlık tarihinde yapılmış en anıtsal türbelerden biri olan Tac Mahal; Hindistan'ın Agra şehrinde, Yamuna Nehri'nin güney kıyısında, çar bağ düzenine sahip bahçe içerisinde; türbe, cami ve mihman hanesi ile büyük bir yapı kompleksi oluşturmaktadır. Yapının banisi Babürlü Devleti'nin beşinci hükümdarı Şah Cihan, türbeyi eși Mümtaz Mahal adına 1631-54 yılları arasında inşa ettirmiş, kendisi de 1666 yılında vefat edince eşinin yanına defnedilmiştir. Tac Mahal hem anıtsal mimarisi hem de süslemeleri ile önemli bir yapıdır. Tac Mahal'in üzerinde yer alan süslemeler genel olarak; bitkisel motifler, geometrik desenler ve hat süslemelerden oluşmaktadır. Tac Mahal'in hat süslemelerini oluşturan yazıtlar, Tac Mahal'in süsleme programının önemli bir parçasını teşkil etmektedir. Tac Mahal'in hat süslemeleri; Darvaza-i-Ravza Kapısı (anıtsal güney giriş bina düzenlemesi), camisi ve türbesinde görülmektedir. Darvaza-i-Ravza Kapısı'nda; güney ve kuzey cephesindeki taç kapı kemerinin yazı kuşağındadır. Türbede; dış cephede, dört yönde de bulunan eyvan şeklindeki taç kapılarının hem iç hem de dış kemerlerinin yazı kuşağında, iç mekânda kemerlerin yazı kuşağında ve bu kemerlerin üzerinde bütün mekânı çevreleyen üst yazı kuşağında türbenin zemin katında ve alt katında bulunan Mümtaz Mahal ve Şah Cihan'ın mezar sandukalarında görülmektedir. Camisinde ise mihrap kemerini çevreleyen yazı kuşağı ile camide yer alan kemerlerin köșeliklerinde bulunan madalyonlar içerisinde görülmektedir. Tac Mahal'de bulunan hat süslemeler; Arapça yazılmış, sülüs, nesih, nestalik ve tuğra yazı stillerinde olup, Kuran'ı Kerim'den sureleri içermektedir. Tac Mahal'in hat süslemeleri, Şirazlı Fakir Emanet Han (Abdul Hak Şirazi) tarafından yazılmıștır (Koch, 2005, s. 145). “Fakir Emanet Han Şirazi" olarak imzası ise türbenin içinde ana mekânda; girince içeride sol tarafta bulunan ilk kemerin yazı kuşağında ve bütün mekânı çevreleyen üst yazı kuşağında bulunmaktadır.

Araştırma kapsamında Tac Mahal'deki hat süslemelerin bulundukları yerleri ile yazı stilleri ve bu süslemeleri olușturan Kuran-ı Kerim'de yer alan surelerin neler

a Arş. Gör. Dr., Erciyes Üniversitesi, fadimeozler@gmail.com 
olduğu ve içerikleri hakkında bilgiler verilmeye çalışılacaktır.

Anahtar kelimeler: Türk-İslam Sanatları Tarihi, Tac Mahal, Abdül Hak Şirazi, Hat Süsleme, Ayet, Sülüs.

$$
\text { 淡淡 }
$$

\section{AN EVALUATION ON THE TAJ MAHAL'S CALLIGRAPHIC ORNAMENTS AND THE SURAHS AND VERSES IN ITS INSCRIPTIONS}

The Taj Mahal, one of the most monumental mausoleums in the history of the world's architecture, constitutes a big building complex with its tomb, mosque and guest house in a char bagh garden on the south bank of the Yamuna River in the Agra city of India. Shah Jahan, the founder of the construction and the fifth ruler of Mughal State, built the mausoleum for his wife Mumtaz Mahal between the years of $1631-1654$, and when he died in 1666, he was also buried next to his wife.

The Taj Mahal is an important construction with both its monumental architecture and its decorations. The decorations of the Taj Mahal include floral motifs, geometrical ornaments and calligraphic ornaments. The inscriptions, which constitute the calligraphic ornaments of the Taj Mahal, are an important part of the decoration pattern of the Taj Mahal. The calligraphic ornaments of the Taj Mahal are on the Darwaza-i Rauza (monumental south gate design), the mosque and the tomb. On the Darwaza-i Rauza, they are on the inscription line of the crown gate arch on the south and north. In the mausoleum, on the outer walls, the inscriptions are on the inscription lines of both interior and exterior arches of the iwan-formed crown gates at four directions. On the interior walls, the inscriptions are on the inscription lines of the arches, upper inscription lines surrounding the whole place over these arches, on the ground floor of the tomb, and on the actual tombs of Mumtaz Mahal and Shah Jahan downstairs...

[The Extended Abstract is at the end of the article.]

$$
\text { 济溫 }
$$

\section{Giriş}

Çok geniş bir coğrafyaya yayılan İslam sanatının sınır tanımayan tek ortak yönü yazıdır. Bu ortaklıkta en büyük etken, İslam'ın kutsal kitabının Arapça yazılmış olmasıdır (Karaçağ, 2002, s. 388). Güzel yazı sanatı, batı dillerindeki kaligrafi, yazıyı göze daha güzel görünecek şekilde yazma gayreti, dünyanın çeşitli çevrelerinde görülür. Yazı üslupları ve tipleri zamanla değişir ve hatta kitabe ve benzerlerini tarihlendirmede başlıca ipucu olarak kullanılır. Ancak, bir sanat olarak en iyi gelişmesini doğu, bilhassa İslam sanatında göstermiştir. Figürlü süslemelerin nadir olduğu İslam çevrelerinde hat sanatı, saf dekorasyon, hatta abstre resim 
mahiyetinde karşımıza çıkmaktadır ve başlı başına bir sanat dalı haline gelmektedir (Demiriz, 1979, s. 31).

Yazı, İslam'ın kabulü ile birlikte Türk sanatında da süslemenin ana unsurlarından biri haline gelmiştir. Birçok Türk-İslam devletinde olduğu gibi Babürlü devletinde de ortaya konulan mimari eserlere bakıldığında yazının, önemli bir süsleme öğesi olduğu anlaşılmaktadır. Araştırmanın konusunu oluşturan Tac Mahal'in hat süslemeleri ise Babürlü mimarisinde yazının mimarideki en gelişmiş örneği olarak gösterilebilir. Tac Mahal'in hat süslemeleri; Darvaza-i-Ravza Kapısı (anıtsal güney giriş bina düzenlemesi), türbesi ve camisi üzerinde bulunmaktadır. Mihman hanesinde hat süslemeye rastlanılmamıştır.

Konuyla ilgili yapılan çalışmalara bakıldığında özellikle Begley ve Desai; Tac Mahal'in yazıt programını kayıt altına alan ve yorumlayan ilk araştırmacılar olmuşlardır. Begley, Wayne E. 1978. "Amanat Khan and The Calligraphy on the Taj Mahal." Kunstdesorients Kunst Des Orients 12 (1-2): 5-60. Wayne Begley bu çalışmada, Tac Mahal'in yazıt programını ve aynı zamanda Emanet Han'ın hattatlığını yapmış olduğu diğer eserler hakkında önemli bilgiler vermektedir.

Ebba Koch Tac Mahal ile ilgili olarak yapmış olduğu araştırmalar ile bilim dünyasına kapsamlı bir çalışma sunmuştur. Koch; Tac Mahal'i bütün yönleri ile ele aldığı "The Complete Taj Mahal” çalışmasında; Tac Mahal'in yazıtlarına dördüncü bölümde yer vermiştir. Koch, bu çalışmada Tac Mahal'de bulunan yazıtları genel bir tarihi yaklaşımla ele almıştır. Yapıda seçilen Kur'ân ayetleri ve kitabelerin malzeme ve estetik özelliklerinden kısaca bahsedilen bu çalışmada hat süslemelerin analizi esas itibariyle yüzeysel olarak incelenmiştir.

Son olarak R. Nath'ın Babürlü dönemi mimari ve sanatı ile ilgili çalışmaları Babürlü dönemini, erken tarih yazımını yeniden yorumlamada önemli bir yere sahiptir. Tac Mahal ile ilgili olarak Nath; The Immortal Taj Mahal: The Evolution of the Tomb in Mughal Architecture ve The Immortal Taj Mahal: The Evolution of the Tomb in Mughal Architecture adlı çalışmalarında; yazıtları kataloglama ötesine uzanan bu araştırmalarında, anıtsal Babürlü yapıları üzerindeki yazının şekli ve içeriği hakkında bilgiler de vermektedir.

Yapılan bu çalışmalar dikkate alındığında özellikle Tac Mahal'in hat süslemelerinin nasıl oluşturulduğu, hangi tekniğin kullanıldığı bunun yanında hangi malzeme ve hangi yazı stillerinin kullanıldığı önemlidir. Yazıtların yer aldığı seçilen duvar yüzeylerinden tercih edilen surelerin nasıl 
bir araya getirildiğine, tek başına ve bir bütün olarak anlamlarına, verdiği mesajların dünya veya ahiret ile ilgili olup olmadığına aynı zamanda yine tercih edilen bu ayetlerin ölen kişiyi mi yoksa gelen ziyaretçileri mi hedef aldığı da aydınlatılması gereken diğer önemli konulardır. Tac Mahal'de bulunan hat süslemeler bulundukları yerlere göre şu şekildedir:

1-Darvaza-i-Ravza Kapısı Üzerinde: Darvaza-i-Ravza Kapısı; ön bahçeden Tac Mahal'in yer aldığı ana bahçeye tek girişi sağlayan güney kapısı yani güney giriș bina düzenlemesidir.

Darvaza-i-Ravza Kapısı'nın güney ve kuzey cephelerinde yer alan taç kapıların kemerini çevreleyen yazı kuşağında hat süslemeler bulunurken doğu ve batı cephelerinin kemerini çevreleyen yazı kuşağının boş bırakıldığı görülmektedir. Kırmızı kumtaşından yapılmış giriş bina düzenlemesi taç kapısının kemerini çevreleyen yazı kuşağı beyaz mermer zemin üzerine siyah renkli taşlarla işlenmiştir.

Kapının güney cephesinde kemeri çevreleyen yazı kuşağında; sülüs hatla Arapça yazılmış Fecr Suresi bulunmaktadır (Fotoğraf 1).



Fotoğraf 1: Darvaza-i-Ravza Kapısı Güney Cephe Genel Görünüşü (Özler, 2016)

Darvaza-i-Ravza Kapısı'nın kuzey cephesinde ise Kuran'ı Kerim'den Duha Suresi, İnşirah Suresi ve Tin Suresi bulunmaktadır.

Kapının kemerini çevreleyen geniş yazı kuşağında sülüs hatla Arapça yazılmış olan bu sureler; iki satır halinde sağdan sola doğru yazılmıştır. Beyaz mermer üzerine kakma tekniği ile siyah renkli oniks taşından 
yapılmıştır.

Ayrıca dış kemer yazı kuşağında sene 1057 (M. 1647) bitiş tarihi bulunmaktadır (Fotoğraf 2).



Fotoğraf 2: Darvaza-i-Ravza Kapısı Kuzey Cephe Genel Görünüşü (Özler, 2016)



Fotoğraf 3: Darvaza-i-Ravza Kapısı Güneybatı Cephe Genel Görünüşü (Özler, 2016) 
programının aynı şekilde güney ve kuzey cephelerde olduğu gibi tekrarlandığı görülürken, kemerleri çevreleyen beyaz mermerden geniş yazı kuşağı her iki cephede de boş bırakılmıştır. Bunun nedeni güney ve kuzey cephelerin kapının giriș açıklıklarına sahip oldukları doğu ve batı cephelerin ise sağır tutulduklarından dolayı yazı kuşağının boş bırakıldığı anlaşılmaktadır (Fotoğraf 3).

2- Tac Mahal Türbesi'nde Bulunan Hat Süslemeler: Türbede; dış cephede taç kapıların-eyvanların kemerlerinde, iç mekânda zemin kattaki ana mezar odasında kemerlerde ve sandukalarda hat süslemeler bulunmaktadır. Türbenin dış cephesinde 5 adet sure yer almaktadır. Dış cephenin genelinde taç kapıların kemerleri üzerinde Yasin Suresi'nin tamamı işlenmiş̧tir. Yapının bütün cephelerinin de kemerini çevreleyen geniş yazı kuşağında Yasin Suresi ile birlikte iç kemer yazı kuşağında; güney cephe iç kemerde Tekvir Suresi, batıda İnfitar Suresi, kuzeyde İnşikak Suresi ve doğudakinde Beyyine Suresi bulunmaktadır.

Cephelerde yer alan Yasin Suresi daha büyük ölçekli olup daha geniş bir yazı kuşağını kapsamakta iken, iç kemerlerinin yazı kuşağının ise daha dar olup, bunun sonucunda yazılarında daha küçük ölçekli ve daha yuvarlak hatlı oldukları görülmektedir. Hat süslemeler kakma tekniği ile beyaz mermer zemin üzerine siyah renkli taşlardan (oniks taşından) oluşturulmuştur. Hat süslemeler Arapça yazılmış, sülüs yazı stili kullanılmıştır.

Güney giriş kapısı üzerinde alt satırdan başlamak üzere besmele-i şerif ile Yasin Suresi'nin ilk ayeti (Kuran-ı Kerim'deki 36'ncı Ayeti) buradan başlamaktadır. Altlı üstlü iki satır halinde sağdan sola doğru ters U şekilde yazı kuşağı kemeri çevrelemektedir (Fotoğraf 4-5-6).



Fotoğraf 4: Tac Mahal Türbesi'nin Güney Cephe Genel Görünüşü (Özler, 2016) 


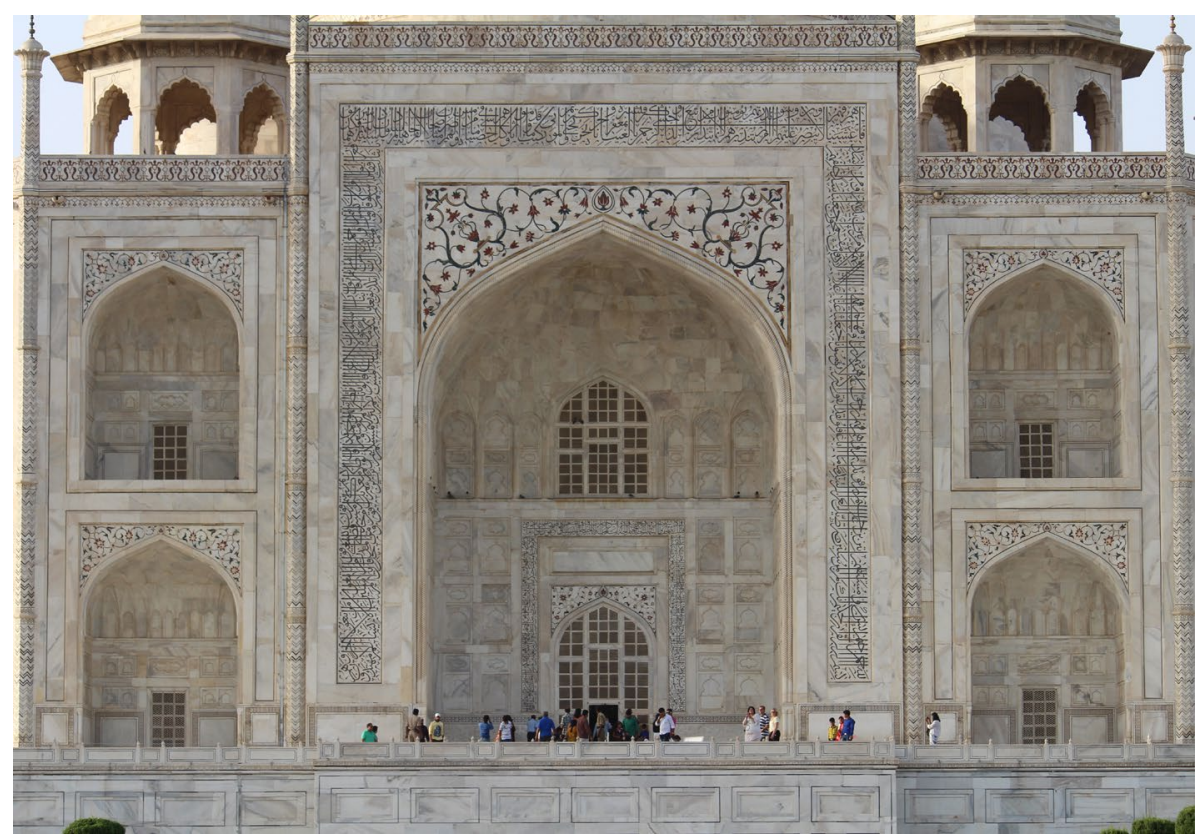

Fotoğraf 5: Tac Mahal Türbesi'nin Güney Cephe Genel Görünüşü (Özler, 2016)

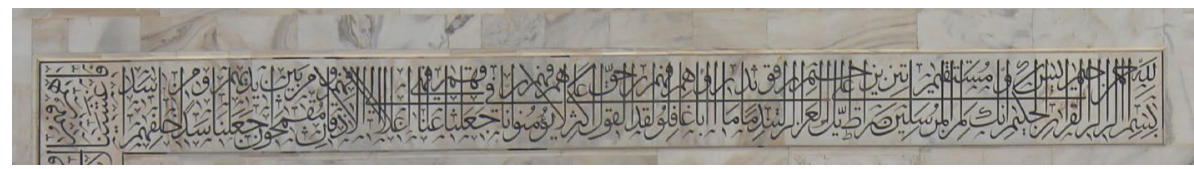

Fotoğraf 6: Güney Cephe Taç Kapıda Yer Alan Yasin Suresi (Özler, 2016)

Güney cephede yer alan taç kapının iç kemer yazı kuşağında; Tekvir Suresi besmele-i şerif ile başlamış sağdan sola doğru ve iki satır halinde altlı üstlü şekilde sülüs hatla Arapça yazılmıştır (Fotoğraf 7-8-9).

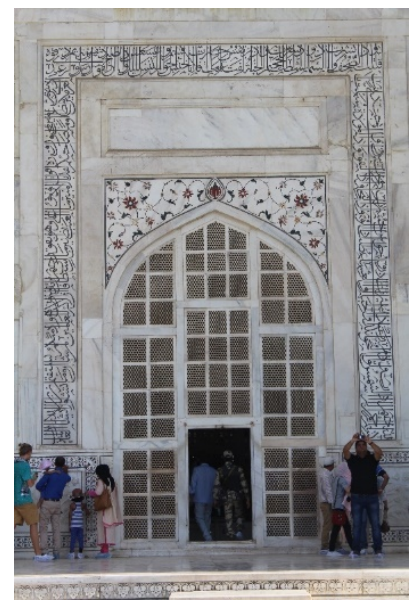

Fotoğraf 7: Güney Cephe Taç Kapıda Yer Alan Tekvir Suresi (Özler, 2016) 


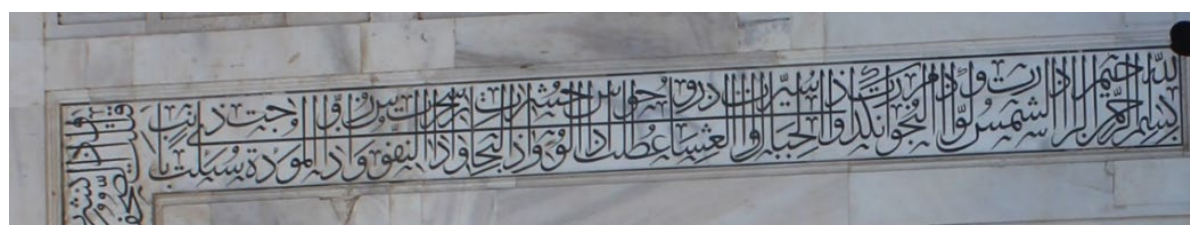

Fotoğraf 8: Güney Cephe Taç Kapıda Yer Alan Tekvir Suresi Detay Görünüşü (Özler, 2016)



Fotoğraf 9: Güney Cephe Taç Kapıda Yer Alan Tekvir Suresi Detay (Özler, 2016)

Batı cephe; Yasin Suresi yine sağdan sola doğru besmele-i şerif ile başlamış ve iki satır halinde altlı üstlü şekilde sülüs hatla Arapça yazılmıştır (Fotoğraf 10).

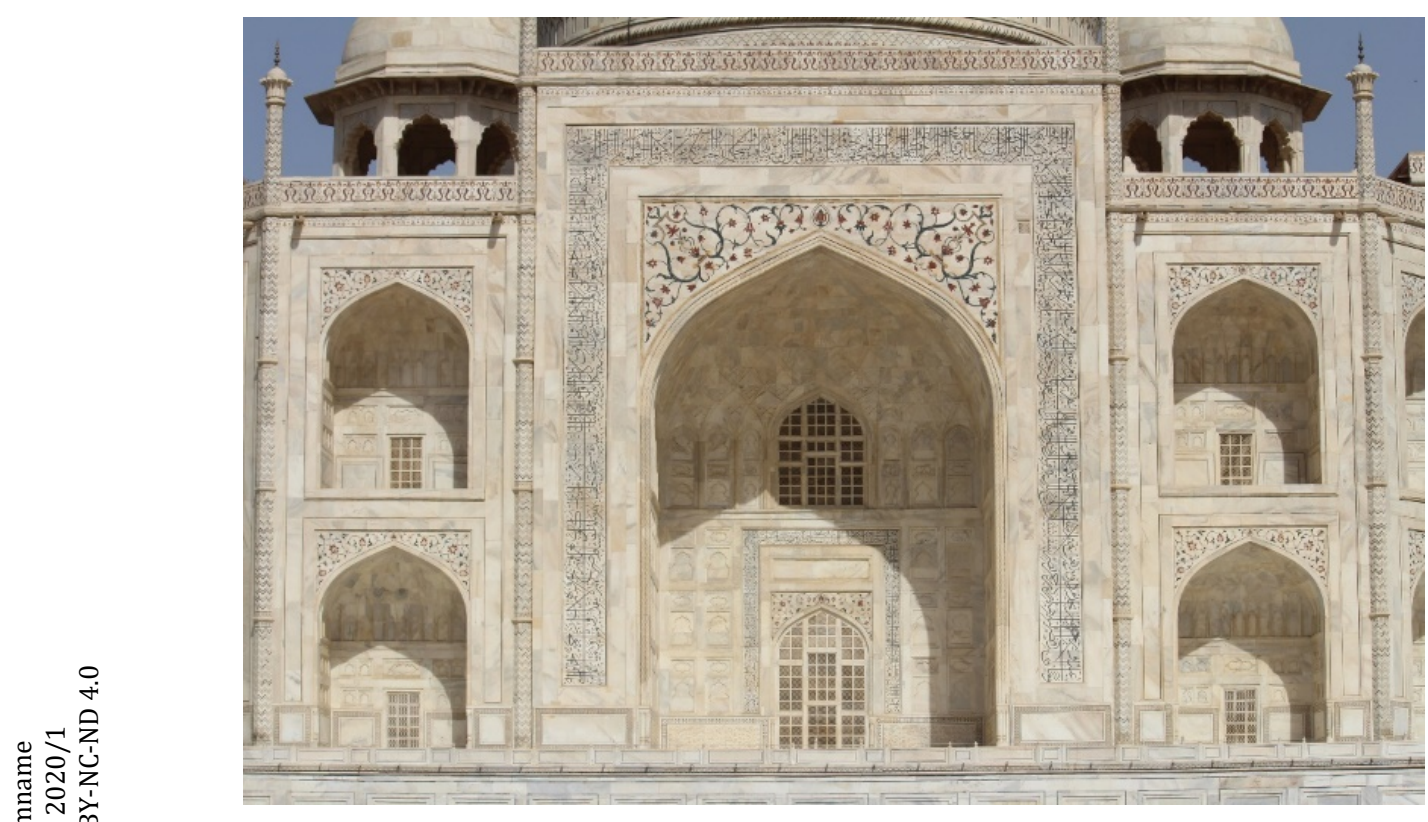

Fotoğraf 10: Batı Cephe Taç Kapıda Yer Alan Yasin Suresi Genel Görünüşü (Özler, 2016) Batı cephesinin taç kapısının iç kemer yazı kuşağında İnfitar Suresi bulunmaktadır. Sure sağdan sola doğru besmele-i şerif ile başlamış ve iki 
satır halinde altlı üstlü şekilde sülüs hatla Arapça yazılmıştır (Fotoğraf 1112-13).

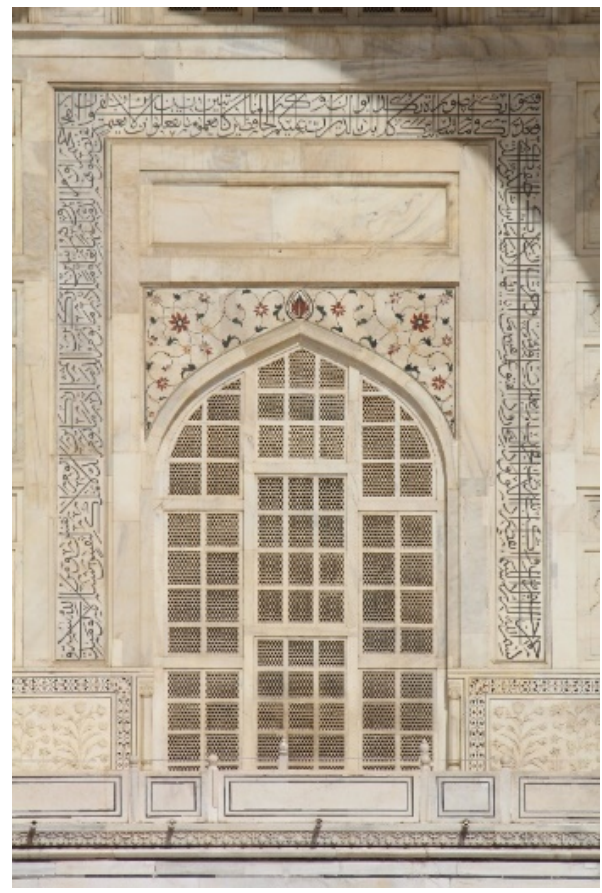

Fotoğraf 11: Tac Mahal Türbesi'nin Batı Cephe Taç Kapıda Yer Alan İnfitar Suresi Genel Görünüşü (Özler, 2016)

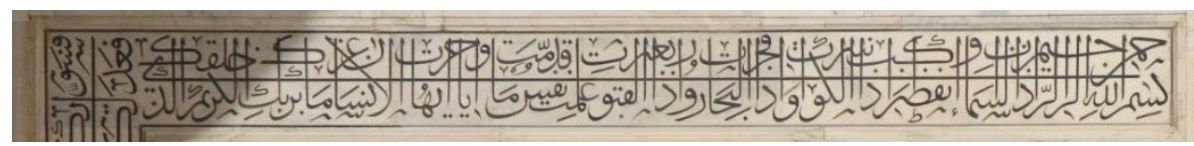

Fotoğraf 12: Türbenin Batı Cephe Taç Kapıda Yer Alan İnfitar Suresi Detay (Özler, 2016)

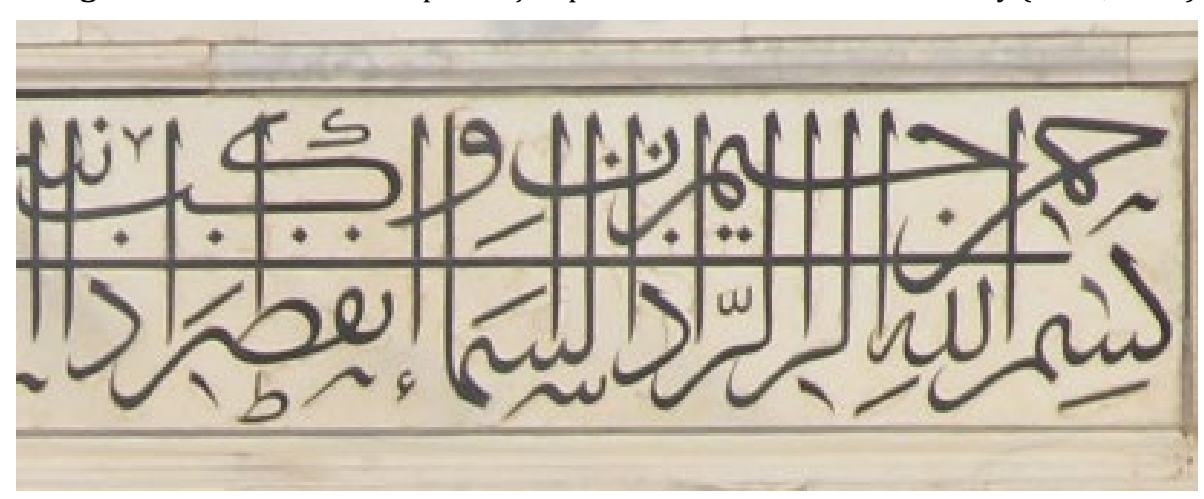

Fotoğraf 13: Türbenin Batı Cephe Taç Kapıda Yer Alan İnfitar Suresi Detay (Özler, 2016)

Ne zaman başladığı yazılı sene 1046 (M. 1636-37) iç kemer yazı kuşağının bitişinde batı cephede bulunmaktadır (Fotoğraf 14). 


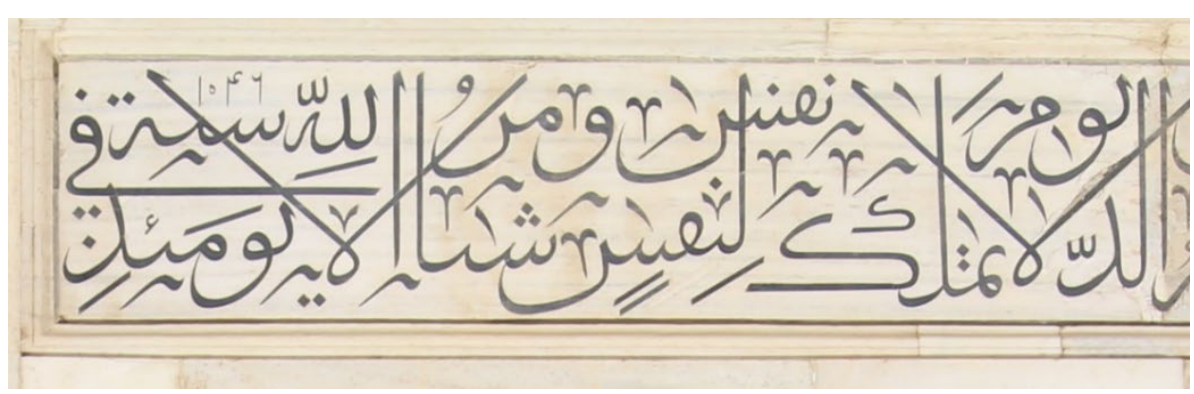

Fotoğraf 14: Batı Cephe Taç Kapı İç Kemerde Yer Alan Tarih Detay Görünüşü (Özler, 2016)

Kuzey cephe; sağdan sola doğru ters U şeklindeki yazı kuşağında sülüs hatla Arapça yazılmış besmele-i şerif ve Yasin Suresi bulunmaktadır (Fotoğraf 15).

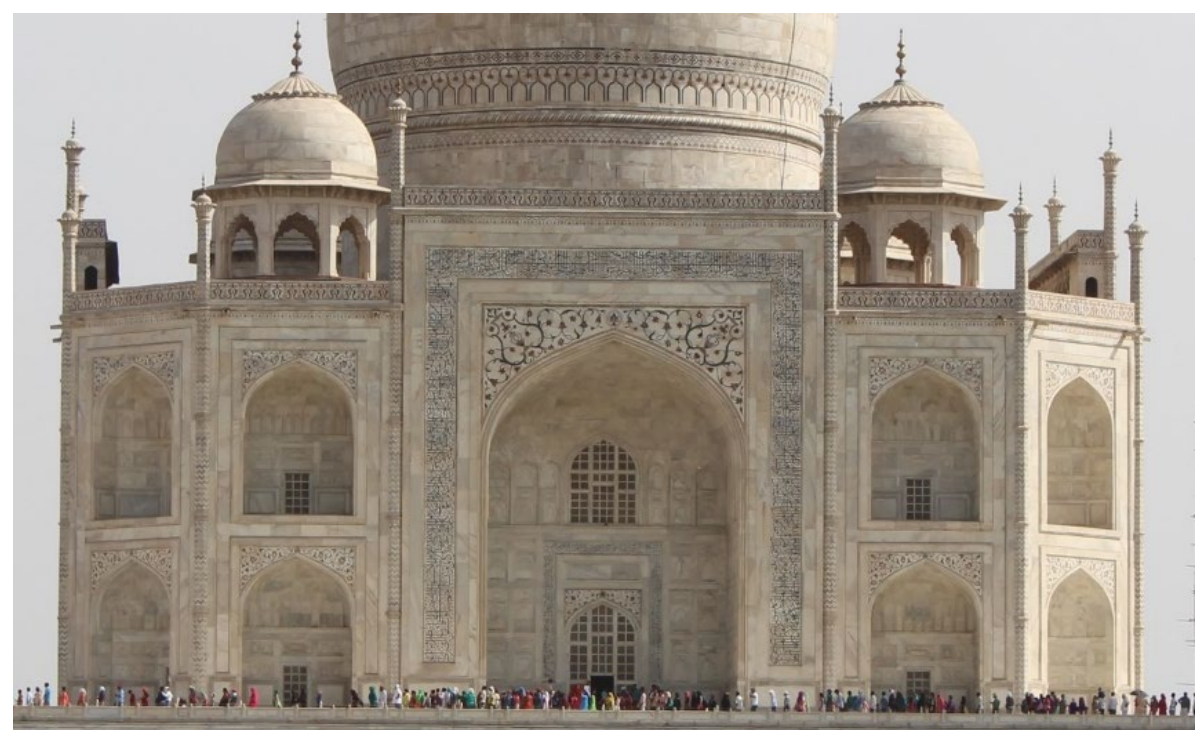

Fotoğraf 15: Kuzey Cephe Taç Kapıda Yer Alan Yasin Suresi Genel Görünüşü (Özler, 2016)

İç kemer yazı kuşağında ise sağdan sola doğru besmele-i şerif ve İnşikak Suresi yer almaktadır İnşikak Suresi de iki satır halinde sülüs hatla yazılmıştır (Fotoğraf 16-17-18). 


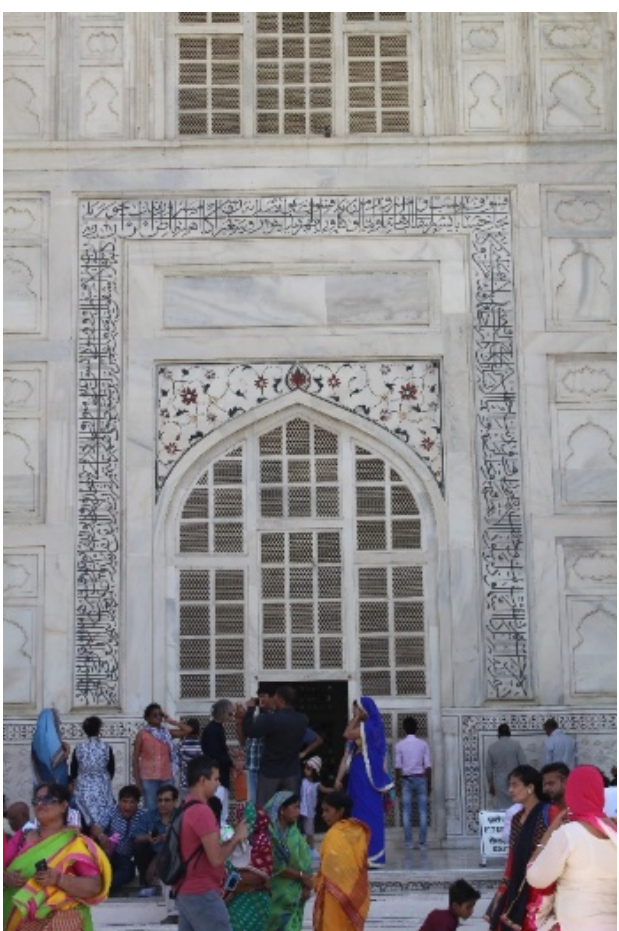

Fotoğraf 16: Tac Mahal Türbesi'nin Kuzey Cephe Taç Kapıda Yer Alan İnşikak Suresi Genel Görünüşü (Özler, 2016)

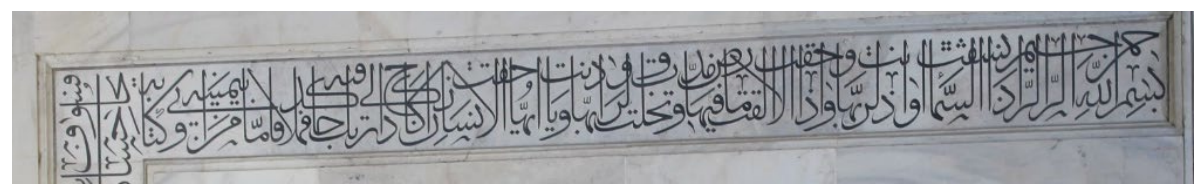

Fotoğraf 17: Tac Mahal Türbesi'nin Kuzey Cephe Taç Kapıda Yer Alan İnşikak Suresi Detay Görünüşü (Özler, 2016)

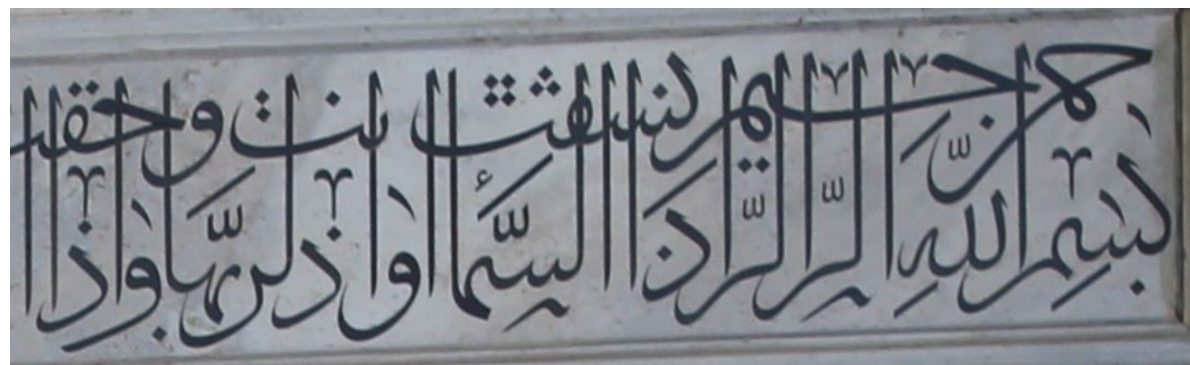

Fotoğraf 18: Tac Mahal Türbesi'nin Kuzey Cephe Taç Kapıda Yer Alan İnşikak Suresi Detay Görünüșü (Özler, 2016)

Doğu cephe; Yasin Suresi sağdan sola doğru besmele-i şerif ile başlamış ve iki satır halinde altlı üstlü şekilde sülüs hatla işlenmiştir. Yasin Suresi bu cephede sona ermiştir (Fotoğraf 19). 


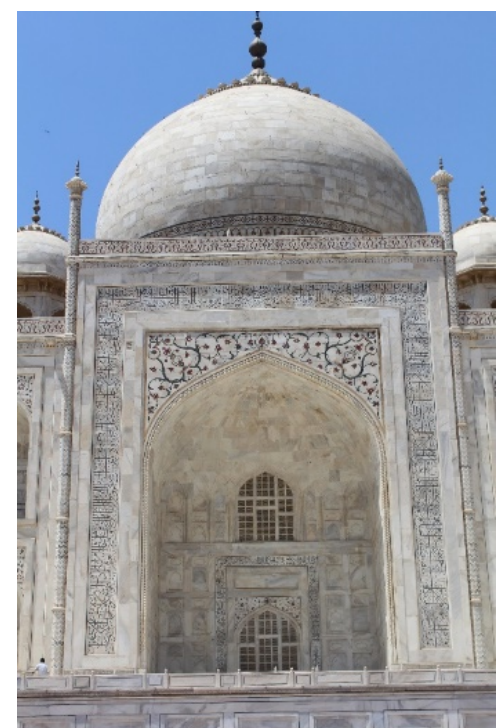

Fotoğraf 19: Türbenin Doğu Cephe Taç Kapıda Yer Alan Yasin Suresi (Özler, 2016)

Taç kapının iç kemer yazı kuşağında ise Beyyine Suresi bulunmaktadır. Sure, sağdan sola doğru besmele-i şerif ile başlamış ve iki satır halinde altlı üstlü şekilde sülüs hatla işlenmiştir (Fotoğraf 20-21-22).

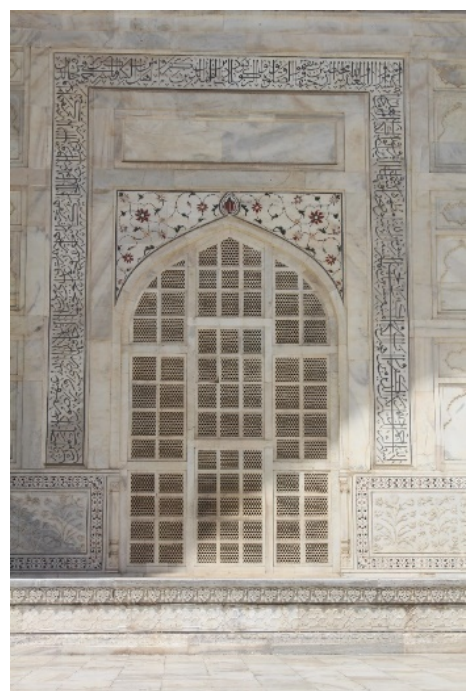

Fotoğraf 20: Tac Mahal Türbesi'nin Doğu Cephe Taç Kapıda Yer Alan Beyyine Suresi Genel Görünüșü (Özler, 2016)

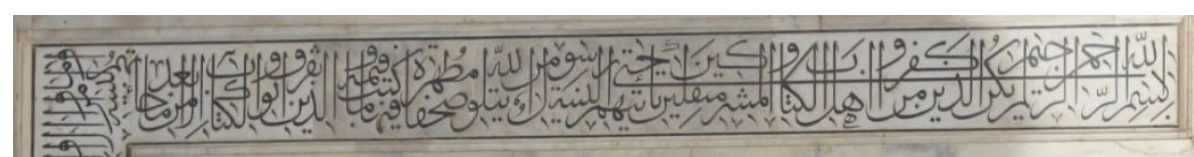

Fotoğraf 21: Türbenin Doğu Cephe Taç Kapıda Yer Alan Beyyine Suresi (Özler, 2016) 


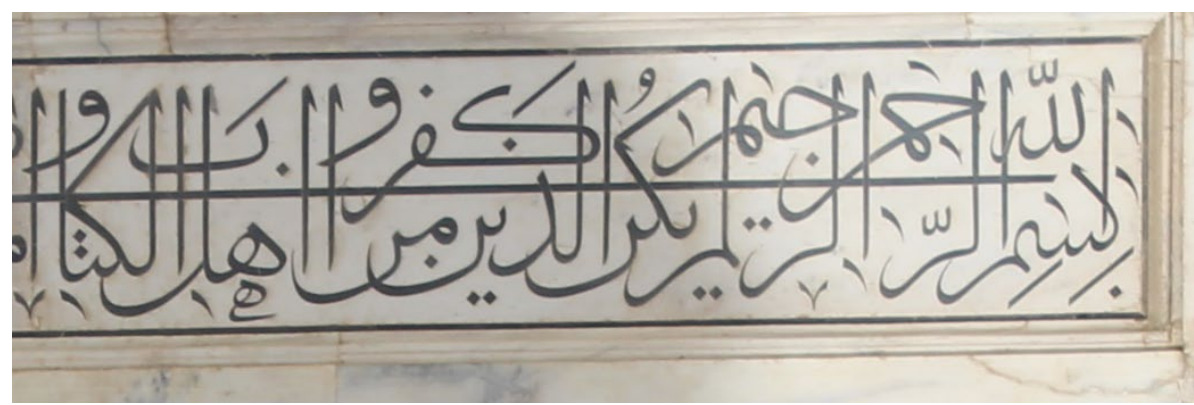

Fotoğraf 22: Türbenin Doğu Cephe Taç Kapıda Yer Alan Beyyine Suresi (Özler, 2016)

Türbenin iç mekânında hat süslemeler; zemin kattaki ana mezar odasında kemer yüzeylerinde, bu katta bulunan sembolik sandukalarda ve alt katta bulunan asıl mezar sandukalarında yer almaktadır. İç mekânda bulunan yoğun bitkisel süslemeler nedeniyle beyaz mermer üzerine siyah renkli taşlarla kakma tekniği ile oluşturulmuş yazı süslemeler oldukça geri planda kalmaktadır. Üstelik ana mekânın loş ışığı yazı süslemelerinin fark edilmesini biraz daha güçleştirmektedir. İç mekânda eyvanların kemer yüzeylerinde geniş yazı kuşağında; Mülk Suresi, Fetih Suresi, İnsan Suresi ve Zümer Suresi bulunmaktadır.

Güneydoğu kemerin yazı kuşağında ve kemerlerin üst yazı kuşağında Mülk Suresi bulunmaktadır.

Güneydoğu, doğu, kuzeydoğu, kuzey, kuzeybatı ve batı kemerlerin yazı kuşağında Fetih Suresi yer almaktadır.

Batı, güneybatı ve güney kemerlerin yazı kuşağında ise İnsan Suresi bulunmaktadır.

Güney kemerin yazı kuşağında ise Zümer Suresi bulunmaktadır.

Ayrıca iç mekânda iki farklı yerde Fakir Emanet Han El- Şirazi'nin imzası bulunmaktadır. Bunlardan birisi; ana mezar odasının girişinin güneyindeki kemerin sol tarafında yazıtın sonunda Fakir Emanet Han ElŞirazi imzası ve sene 1048 (M. 1638) tarihi şeklindedir. Diğeri de iç mekânda kemerlerin üzerini çevreleyen geniş yazı kuşağında da yine Fakir Emanet Han El- Şirazi şeklinde yer almaktadır (Fotoğraf 23-24-25-26). 


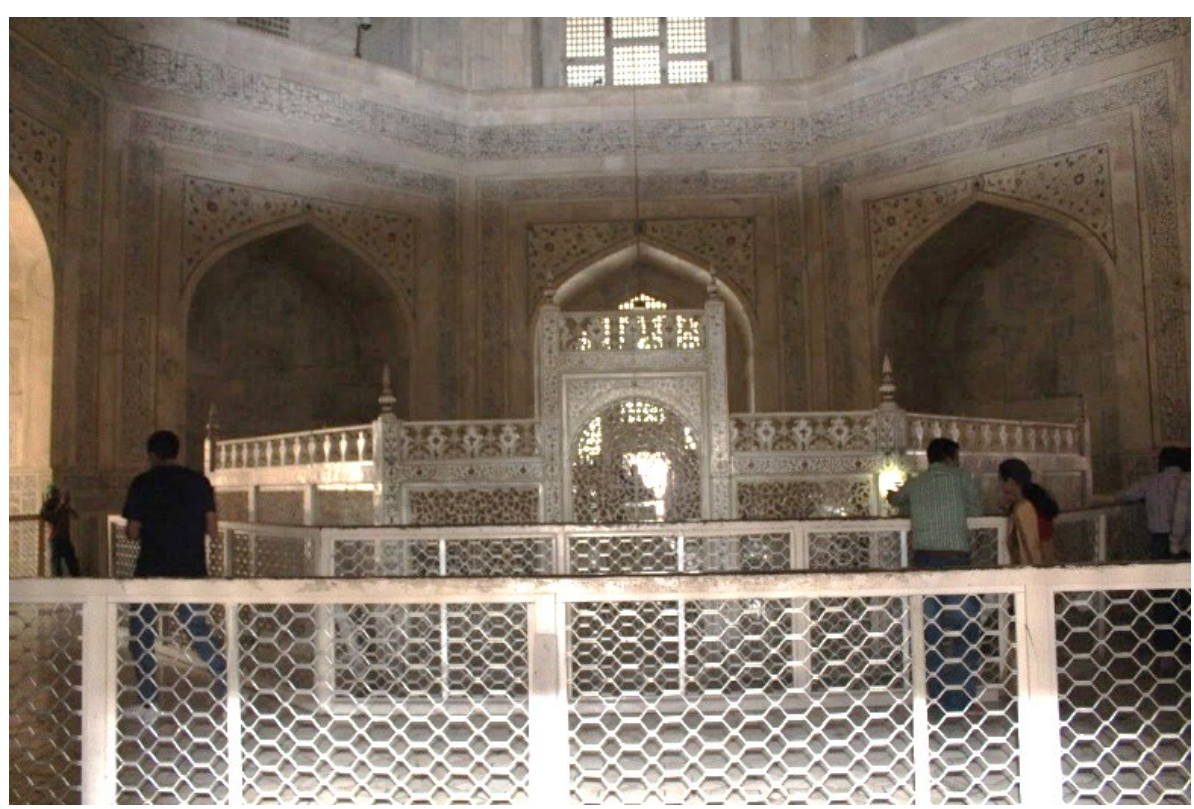

Fotoğraf 23: Türbenin İç Mekânda Yer Alan Yazı Süslemeleri Genel Görünüşü (Özler, 2016)



Fotoğraf 24: Türbenin İç Mekânda Yer Alan Yazı Süslemeleri Genel Görünüșü (Özler, 2016) 


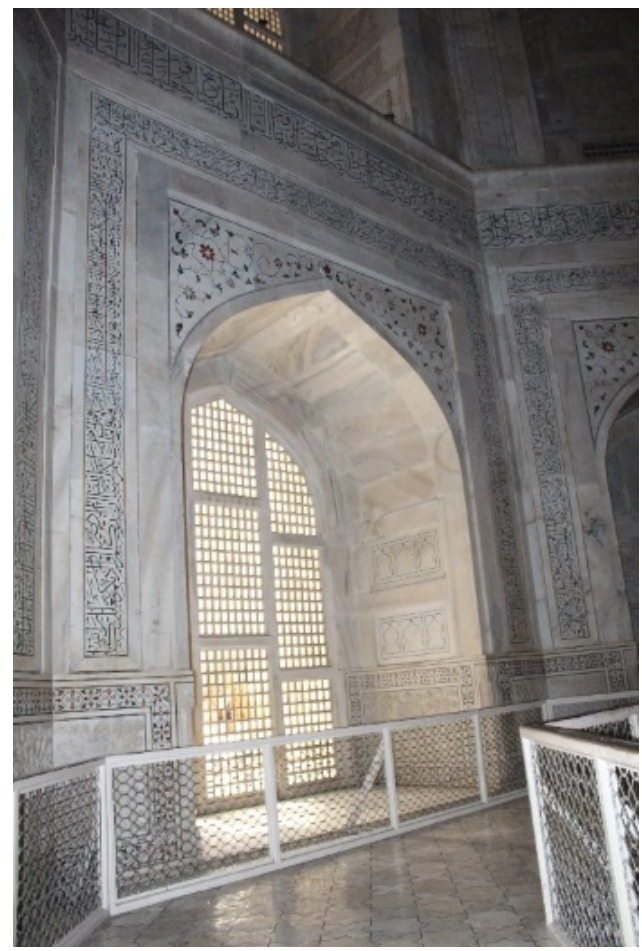

Fotoğraf 25: Türbenin İç Mekânda Yer Alan Yazı Süslemeleri Genel Görünüşü (Özler, 2016)

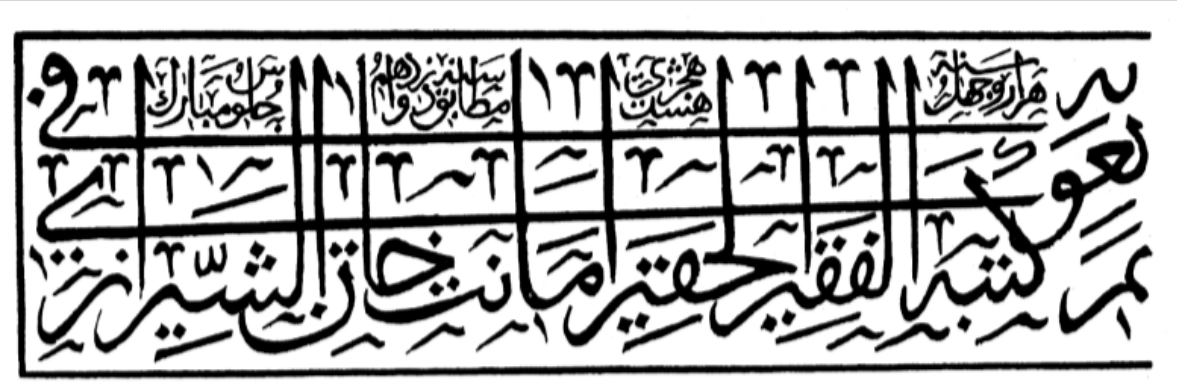

Fotoğraf 26: Türbenin İç Mekânda Güney Kemerinde Yer Alan Yazı Süslemeleri Detay Görünüşü (Begley, 1978-79)

Sandukalarda bulunan hat süslemeleri ise zemin katta bulunan sembolik sandukalar ve alt katta cenazelikte bulunan asıl mezar sandukalar şeklinde ele almak gerekmektedir. Zemin katta bulunan sandukalar üzerinde Şah Cihan'ın sandukası üzerinde yazıya rastlanılmazken, Mümtaz Mahal'in sandukası üzerinde; Fussilet Suresi, Mü'min Suresi, Mutaffifin Suresi, Bakara Suresi, Haşr Suresi bulunmaktadır. Alt katta yer alan asıl mezar sandukalarının üzerinde ise Zümer Suresi, Ali İmran Suresi, Mü'minun 
Suresi, Haşr Suresi ve Esma-ül Hüsna (Allâhü Teâlâ'nın 99 ismi) oluşturmaktadır. Mümtaz Mahal'in hem zemin hem de alt kattaki sandukaları üzerindeki hat süslemelerinde nestalik yazı stili tercih edilirken, Şah Cihan'ın sadece alt kattaki sandukasında bulunan hat süslemelerinde nesih yazı stili kullanılmıştır. Hat süslemeler, beyaz mermer üzerine siyah renkte taşlarla kakma tekniği ile oluşturulmuştur (Fotoğraf 27-28).

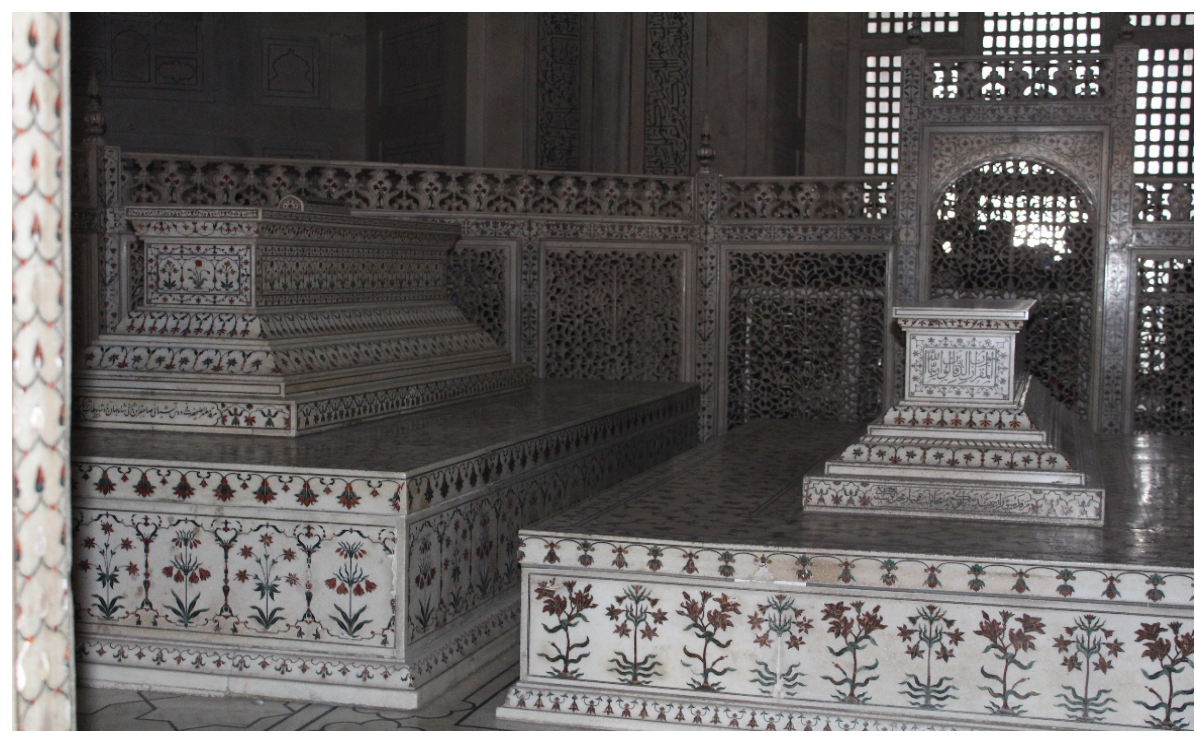

Fotoğraf 27: Şah Cihan ve Mümtaz Mahal'e ait Sembolik Mezar Sandukaları (Özler,2016)

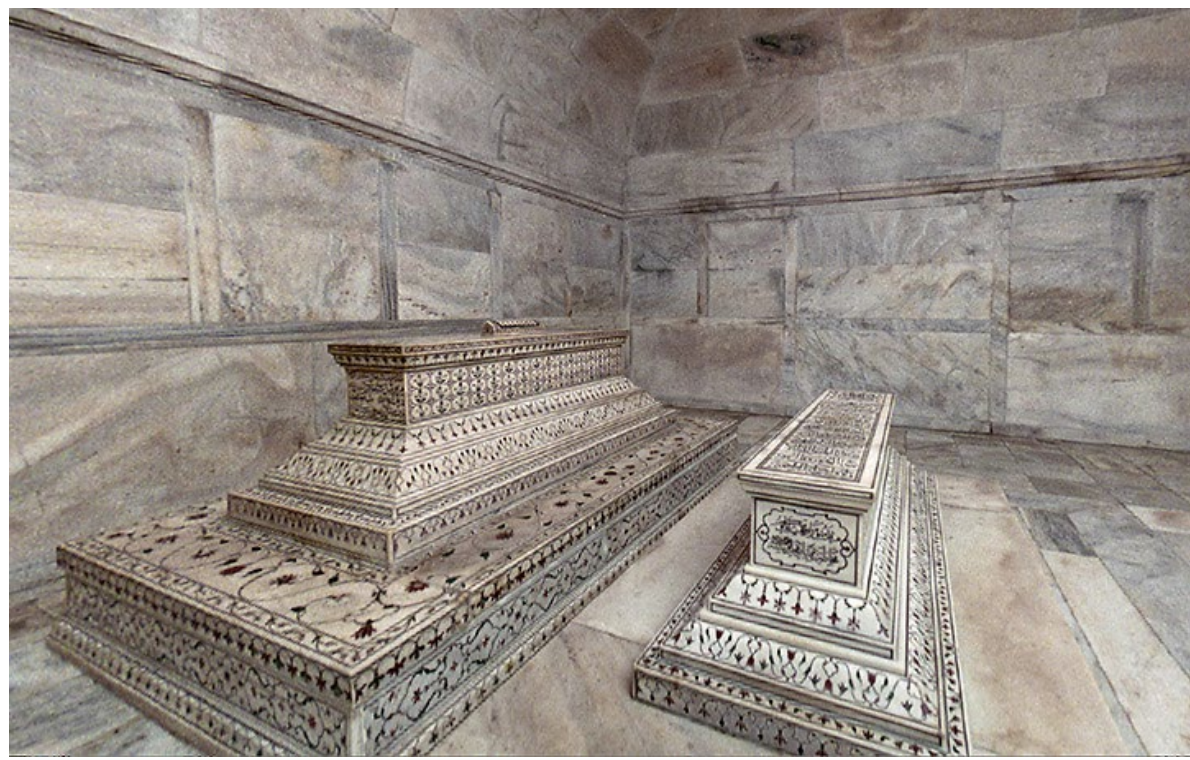

Fotoğraf 28: Alt Katta Yer Alan Şah Cihan ve Mümtaz Mahal'e ait Mezar Sandukaları http://www.gotoagra.com/2016/03/taj-mahal-agra.html 
3- Camisi'nde Mihrap Üzerinde ve Kemer Köşeliklerindeki Madalyonlarda: Türbenin her iki yanında simetrik olarak yer alan doğuda mihman hanesi batıda camisi kırmızı kumtaşından yapılmış üzerleri beyaz mermerden üçlü kubbe ile örtülmüştür. Her iki yapının da dış cephede yer alan taç kapısının kemerindeki geniş yazı kuşağının boş bırakıldığ görülmektedir. Ancak camisinin mihrabı üzerinde hat süslemeler bulunmakta ve kırmızı kumtaşı ve beyaz mermerden oluşan mihrabın kemerini çevreleyen geniş sivri kemer formunu alan yazı kuşağının beyaz mermer üzerine siyah renkte Kur'an-ı Kerim ayetleri ile doldurulduğu görülmektedir. Mihrap kemerindeki geniş yazı kuşağında sülüs hatla Şems Suresi bulunurken; İhlas suresi, "Ya Kâfi", "Allah", "Kelime-i Tevhid" ve "Kelime-i Şehadet" bütün cami genelinde bulunan kemerlerin kemer alınlığında madalyonlar içerisinde tuğra yazı hattı ile oluşturulmuştur (Fotoğraf 29-30-31-32-33-34).



Fotoğraf 29-30: Tac Mahal Camisi İçerden Genel Görünüşleri (Özler, 2017) 




Fotoğraf 31: Tac Mahal Camisi Mihrabı Genel Görünüşü (Özler, 2017)

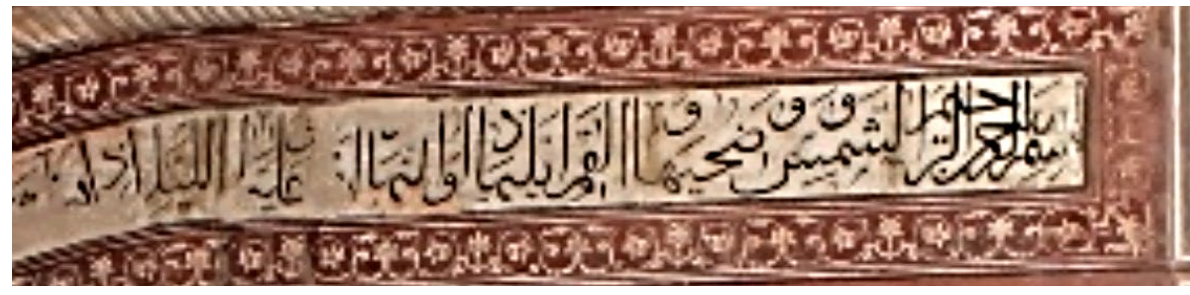

Fotoğraf 32: Tac Mahal Camisi Mihrabında Yer Alan Şems Suresi Detay (Özler, 2017)

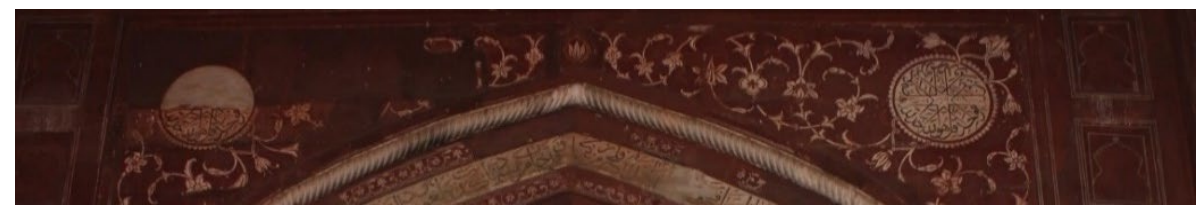

Fotoğraf 33: Tac Mahal Camisi Mihrabı Detay Görünüşü (Özler, 2017)

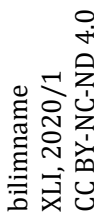

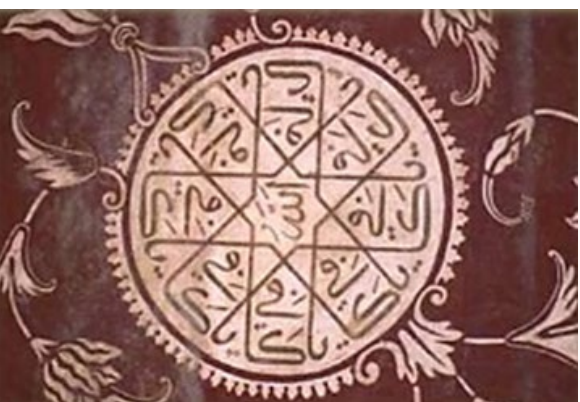

|1008|

Fotoğraf 34: Tac Mahal Camisi Mihrabı Detay Görünüşü (Özler, 2017) 


\section{Değerlendirme}

Değerlendirme bölümü üç ana başlıkta toplanmıștır. Birinci bölümde Tac Mahal'de Kur'an-ı Kerim'deki hangi sure ve ayetlerin yer aldığı bu ayetlerin konuları ile vermek istedikleri mesajların neler olduğu üzerinde durulmuştur. İkinci bölümde; bu sure ve ayetlerin yazı stilleri hakkında bilgiler verilmiştir. Üçüncü ve son bölümde ise Tac Mahal'in hat süslemelerinin aynı şehirde yer alan ve çağdaşı olan İtimadu'd-Devle Türbesi ile hem stil hem de içerik olarak hat süslemelerinin karşılaştırılması yapılmıştır.

A-Tac Mahal'de Yer Alan Sureler ve Konulart: Tac Mahal'in Darvazai-Ravza kapısı, türbesi ve camisinde bulunan hat süslemelerini Kuran'ı Kerim'den şu sureler oluşturmaktadır:

1- Fecr Suresi: Fecr Suresi, Darvaza-i-Ravza kapısının güney cephe taç kapı kemeri üzerinde bulunmaktadır.

Fecr Suresi Mekke'de inmiştir. Kur'an-ı Kerim'in 89'uncu suresi olup, 30 ayettir (Yazır, 2007, s. 195). Sure ismini başındaki "fecr" kelimesinden alır. "Şafak sökmesi, tan yerinin ağarması" veya "şafak vakti, tan yeri" anlamına gelen fecre yemin ile başlayan sureye "Ve'l-Fecri" suresi de denilir ve Mushaf'taki tertibe göre "Ve'l-Leyl", "Ve'd-Duhâ" gibi belli vakitlere yeminle başlayan surelerin önünde yer alır (Işık, 1995, s. 290).

Konusu: Surenin konusunu, genellikle Mekkî surelerde görüldügü üzere iman ve sâlih amel yolunu terk edenlerin dünya ve ahirette karşılaşacakları kötü âkıbetle iman ehlinin her iki cihanda erişeceği mutluluk hakkındaki açıklamalar oluşturmaktadır (Işık, 1995, s. 290). 0 gün kimsenin kimseden yardım göremeyeceği ve hiç kimsenin bir başkasının yerine cezalandırılmayacağı vurgulandıktan sonra sure, nefsânî hırslarına gem vurup gönül rızası ve teslimiyetle Allah'ın emirlerine itaat edenlerin kendileri gibi iyilerin arasına katılacaklarını ve cennete gireceklerini müjdeleyen ayetle sona erer (Işılk, 1995, s. 291).

2- Duha Suresi: Darvaza-i-Ravza kapısı kuzey cephe kemeri üzerinde bulunmaktadır.

Duha Suresi Mekke'de inmiştir. Kur'an-ı Kerim'in 11 ayetten oluşan 93'üncü suresidir (Yazır, 2007, s. 288). Fecr Suresi'nden sonra Mekke'de inen Duha, kuşluk vakti demektir. Sure, adını ilk ayette geçen bu kelimeden alır.

Konusu: Duhâ Suresi, İslâm güneşinin yükselişini sembolize eden kuşluk vaktiyle küfür ve şirk döneminin, bitmeye yüz tutmuş karanlık bir 
geceyi andıran haline yeminle başlar. Allah'ın Hz. Peygamber'i terk etmediği ve kendisine darılmadığı bildirilir. Hz. Peygamber'i yakın bir gelecekte büyük başarıların beklediği, peygamberlik görevinin sonunun başlangıcından daha hayırlı olacağı müjdelenir. Aslında Hz. Peygamber annesiz babasız büyüyen bir yetimken Rabbi kendisini koruyup kollamış ve ona peygamberlik vermiştir. Artık rabbin desteğinden uzak kalması ve terkedilmiş bir duruma düşmesi söz konusu değildir (Işıık, 1994, s. 546).

3- İnşirah Suresi: Darvaza-i-Ravza kapısı kuzey cephe kemeri üzerinde, yazı kuşağında bulunmaktadır.

İnşirah Suresi Kur'an-ı Kerim'in 94'üncü suresidir. Sekiz ayetten oluşan sure, Mekke'de inmiştir (Yazır, 2007, s. 313).

Konusu: İnşirah Suresi'nin, "Senin üzerinden ağır bir yükü kaldırdık" mealindeki ayetiyle, peygamberlikten önce veya peygamberliğin ilk dönemlerinde Resûlullah'ı çok üzen ve tahammülü güç olan zorlukların kaldırılması kastedilmiştir. Surede, güçlükle beraber kolaylığın bulunacağına iki defa vurgu yapılması bir yandan Resûl-i Ekrem'in, karşılaşacağı şiddetli engelleme ve zorlukların rahatlama ile sonuçlanacağına kesin olarak güvenmesini sağlamayı amaçlamakta, öte yandan müminlere mâruz kalacakları sıkıntı ve haksızlıklar karşısında yılgınlığa düşmemelerini, Allah'a daima güvenmelerini, iyimserliklerini koruyup güzel günler için çalışmalarını telkin etmektedir. Nihayet surenin sonunda Hz. Peygamber'in şahsında bütün müminlerden Allah'a bağlllıklarını sürdürmeleri istenmektedir (Yaşaroğlu, 2000, s. 346).

4- Tin Suresi: Darvaza-i-Ravza kapısı kuzey cephe kemeri üzerinde bulunmaktadır.

Tin Suresi Mekke'de inmiştir. Sekiz ayet olup, Kur'an-ı Kerim'in 95'inci suresidir. Burûc suresinden sonra nâzil olmuştur. Adını ilk ayette geçen "tîn" (incir) kelimesinden alır (Yazır, 2007, s. 329).

Konusu: Surede bazı önemli varlıklar üzerine yemin edilerek insanın yüksek değeri vurgulanmıș, kötü ahlâkın bu değeri düşürdüğü ifade edilmiştir. İman edip iyi işler yapanlar övülmüş, hesap ve cezayı yalan sayanlar kınanmış, hüküm verenlerin en üstününün Allah olduğu bildirilmiştir. Surenin son iki ayetinde insanın sorumluluk duygusunu en güçlü biçimde etkileyen ahiret hayatı, herkesin dünyada yaptığının karşılığını bulacağı ebediyet âlemi hatırlatılmakta, zihni ve gönlü gerçeklere açık olan insanlar tarafından o günün hiçbir bahane ile inkâr edilemeyeceği, ayrıca en âdil hükmün Allah tarafından verileceği vurgulu biçimde ifade edilmektedir (Birışık, 2012, s. 189). 
5- Yasin Suresi: Türbenin bütün cephelerinin taç kapı kemer yüzeylerinde bulunmaktadır.

Yasin Suresi Mekke döneminde inmiştir (Yazır, 2007, s. 437). Yasin Suresi Kur'an-ı Kerim'de 36'ncı suredir, 83 ayetten oluşmaktadır ve adını ilk ayeti olan "Ya-Sin" harflerinden alır.

Konusu: Sure; "Kalbü’l Kur'an" şeklinde adlandırılmıştır. Yasin Suresi'nde İslâm akaidinin üç esasını teşkil eden tevhid, nübüvvet ve ahiret konuları tabiatın mükemmel kuruluşu ve işleyişinden deliller getirilerek anlatılır; bu arada iman-küfür mücadelesi çerçevesinde geçmiş kavimlerden ibret verici örnekler zikredilir (Topaloğlu, 2013, s. 340-41).

6- Tekvir Suresi: Güney cephede taç kapıda iç kemerde yazı kuşağında bulunmaktadır.

Tekvir Suresi Mekke'de inmiştir. Sure, Kur'an-ı Kerim'in 81'inci suresi olup, 29 ayetten oluşmaktadır (Yazır, 2007, s. 7).

Konusu: Kıyametin kopmasını ve Kur'an'ın vahiy ürünü oluşunu konu alan Tekvîr Suresi'nde Allah tarafından konulan tabiat kanunlarının değiştirilerek güneşin, yıldızların, dağların, denizlerin, vahşi hayvanların tersine çevrileceğine temas edilir; ardından büyük hesap gününün kısa tasviri yapılır ve o gün kişinin ebedî hayat için önceden neler hazırladığının bilincinde olacağı belirtilir (ayet 1-14). Tabiatın işleyişine dair birçok ayette görüldügü üzere yıldızların çeşitli görünümlerdeki seyrine, kararmaya yüz tutan geceye ve ağarmaya başlayan sabah vaktine yemin edilerek Kur'an'ın vahiy eseri olduğu ifade edilir, onun değerli ve itibarlı bir elçi (Cebrâil) tarafından Resûlullah'a getirildiği bildirilir. Ardından "arkadaşınız" diye nitelendirilen Hz. Muhammed'in inatçı inkârcıların iddia ettiği gibi bir mecnun olmadığı, gayb âlemine ait gerçekleri gizlemediği, bildirdiği tebliğin şeytandan gelmediği vurgulanır (ayet 15-25). Surenin son dört ayeti, "Bu açık gerçeklere rağmen siz nereye gidiyorsunuz?" sorusuyla başlar ve Kur'an'ın doğru yola girmek isteyen herkes için bir uyarıcı ve öğütçü olduğu vurgulanır; ancak doğru yola girme talebinin ilâhî irade doğrultusunda yapılmasının şart koşulduğu belirtilir (Topaloğlu, 2011, s. 390).

7- İnfitar Suresi: Batı cephesinin taç kapısının iç kemer yazı kuşağında bulunmaktadır.

İnfitar Suresi Mekke'de inmiştir, Kur'an-ı Kerim'in 82'nci suresi olup, 19 ayetten oluşmaktadır (Yazır, 2007, s. 47).

Konusu: Surenin ilk bölümünde (ayet 1-5) yer ve gökle ilgili bazı kıyamet olayları tasvir edilerek göğün yarılacağı, yıldızların etrafa saçılacağı, 
aradaki engeller kaldırılarak deniz sularının birbirine karıştırılacağı ve kabirdekilerin dışarıya çıkarılacağı belirtilir. Daha sonra hesap gününün büyüklüğü tasvir edilir, Hz. Peygamber'e yöneltilen soru cümleleriyle ahiret gününün dehşeti tekrar vurgulanır ve herkesin bütün gücünden soyutlandığı o günde yalnızca Allah'ın emrinin geçerli olduğu belirtilir (ayet 17-19). Surede kıyamet koparken evrende meydana gelecek olan değişim ve bazı dehşet verici olaylar, öldükten sonra dirilme, mahşerde hesap verme ve itaatkâr kulların varacakları cennetle isyankâr kulların gideceği cehennem gibi konular yer almaktadır (Yaşaroğlu, 2000, s. 294).

8- İnşikak Suresi: Türbenin kuzey cephede yer alan taç kapısının iç kemer yazı kuşağında bulunmaktadır.

İnșikak Suresi ihtilafsız Mekke'de inmiștir. Kur'an-ı Kerim'in 84'üncü suresi olup, 25 ayetten oluşmaktadır (Yazır, 2007, s. 83). Sure, adını birinci ayette geçen "inşakka" fiilinin mastarı olan "İnşikâk" kelimesinden almıştır. İnşikâk, yarılmak demektir. Mekke döneminde inmiştir.

Konusu: Üslûp ve muhteva bakımından Mekke döneminde nâzil olan diğer surelerle benzerlik arzeden surenin ilk bölümünde (ayet 1-5), kendisinden önce inen İnfitâr Suresi'ndekine benzer tarzda bazı kıyamet sahnelerinden bahsedilerek göğün parçalara ayrılacağı, yeryüzünün dümdüz hale getirileceği ve yerin içindeki her şeyi dışarı atacağı belirtilmiştir. Surede kıyametin kopması, onun ardından gerçekleşecek olan uhrevî hesap, insanların iman ve amellerine uygun yargılama, ceza ve ödül gibi konular etkili bir üslûpla verilmektedir (Yaşaroğlu, 2000, s. 343).

9- Beyyine Suresi: Türbenin doğu cephedeki taç kapısının iç kemer yazı kuşağında bulunmaktadır.

Beyyine Suresi; Kayyime Suresi, Münfekkin Suresi, Beriyye Suresi, Lemyekün Suresi de denilen sure; Medine'de inmiştir ancak Mekke ve Medine döneminde inmiş olduğu konusunda ihtilafa düşülmüştür (Yazır, 2007, s. 381).

Kur'an-ı Kerim'in 98'inci suresi olup, 8 ayetten oluşmaktadır. İsmini açık delil manasına gelen ve ilk ayette geçen "el-beyyine" kelimesinden almıștır.

Konusu: Surenin ilk beş ayetinde, gerek Ehl-i kitap'tan olan inkârcıların gerekse müşriklerin Hz. Peygamber'in zuhuruna kadar bu durumlarını sürdürdükleri hatırlatılmış, Tevrat ve İncil'de geleceği bildirilen peygamberin henüz gönderilmemiş olmasını bu tutumlarının bir mazereti olarak ileri sürdüklerine işaret edilmiştir. Ancak Hz. Peygamber'in gelişinden sonra artık özellikle Ehl-i kitab'ın topyekün hak dini kabul etmeleri 
gerekirken böyle olmadığı belirtilerek bunlardan bir kısmının İslâm'a yöneldiklerine, diğerlerinin ise aynı inkâr üzere kaldıklarına dikkat çekilmiş, kendilerinden beklenenin ise samimiyetle ve sadece Allah'a kulluk etmeleri, namazı dosdoğru kılıp zekâtı vermeleri olduğu vurgulanarak hak dinin ve gerçek dindarlığın temel ilkeleri ortaya konmuştur. Sure kötülerle iyilerin ahiretteki durumlarını özetleyen açıklamalarla son bulmaktadır (Işık, 1992, s. 98-99).

10- Mülk Suresi: İç mekânda zemin ana mezar odasının güneydoğu kemerin yazı kuşağında ve yine ana mezar odasının kemerlerin üst yazı kuşağında bulunmaktadır.

Bu surenin Mülk'den başka Tebareke, Mania, Münciye, Mücadele, Vakiye ve Mennaa gibi isimleri de vardır. İniş yeri Mekke'dir (Yazır, 2007, s. 193). Kur'an-ı Kerim'in 67'nci suresi olup, 30 ayetten oluşmaktadır. Surenin adı 1'inci ayette geçer. "Tebâreke Suresi" diye de anılır.

Konusu: Mülk Suresi'nin temel konusunun Allah'ın varlığını, birliğini, kâinatı yaratıp yönettiğini ve ahiretin mevcudiyetini kanıtlamak olduğunu söylemek mümkündür. Surenin muhtevası iki bölüm halinde açıklanabilir. Kâinatın yaratılış ve yönetiliş iktidarının Allah'ın elinde bulunduğunun ifadesiyle başlayan birinci bölümün ilk ayetlerinde içinde yaşanılan âlemin bir imtihan dünyası olduğu belirtilir, ardından ilâhî kudretin tabiata verdiği mükemmeliyetten bazı örnekler zikredilir. İkinci bölümde, sema örneğiyle evrenin mükemmelliğine işaret edilen birinci bölüme karşılık arzın, insan türünün yaşamasına uygun hale getirilişiyle ilâhî lütuf ve kudrete temas edilmiş, kuş türünün tabiattaki mükemmel konumuna değinilmiş, insana verilen zahirî ve bâtıni yetenekler hatırlatılmış, tabiatta hâkim olan ilâhîtabii kanunların aksaması durumunda insanın elinden hiçbir şey gelmeyeceği belirtilmiştir. Bütün bunlara rağmen geçmiş peygamberler döneminde olduğu gibi (ayet 18) dinî gerçekleri yalanlamaya devam edenlerin akıbetlerinin elem verici bir hayat olacağı ifade edilmiştir (Yaşaroğlu, 2006, s. 542).

11- Fetih Suresi: İç mekânda zemin ana mezar odasının güneydoğu, doğu, kuzeydoğu, kuzey, kuzeybatı ve batı kemerlerin yazı kuşağında yer almaktadır. Fetih Suresi Medine'de inmiştir ancak Medine'nin içinde indirilmiş manasına değil, hicretten sonra indirilmiş manasına Medenidir. Çünkü hicretin altıncı yılı seferde Hudeybiye dönüşünde Mekke civarında indirilmiştir (Yazır, 2007, s. 165). Kur'an-ı Kerim'in 26'ncı suresi olup, 29 ayetten oluşmaktadır.

Konusu: Ana konu Hudeybiye Antlaşması'nın değerlendirilmesi, 
niyetlendikleri umre ibadetini yapamadan döndükleri için büyük üzüntü ve hayal kırıklığı içinde olan müminlerin teselli edilmesi, bu harekât içinde ve sonrasında olup bitenlerin Allah nezdindeki değerinin açılanmasıdır. $\mathrm{Bu}$ genel çerçeve içinde Hz. Peygamber ve ashabının Allah katındaki durum ve dereceleri, onları ibadetten meneden müşrikler ile yalnız bırakan münafıkların acı sonları hakkında önemli bilgiler verilmiş, bu barışı takip edecek olan fetihler müjdelenmiştir (Diyanet İşleri Başkanlığı, 2020, s. 3).

12- İnsan Suresi: İç mekânda zemin ana mezar odasının batı, güneybatı ve güney kemerlerin yazı kuşağında bulunmaktadır.

Adını, insanın yaratılmadan önceki hiçliğini ifade eden birinci ayetteki "insân" kelimesinden alır. İnsan Suresi, Dehr Suresi, Ebrar Suresi, Emşac Suresi ve Hele ta Suresi de denilen bu mübarek surenin Mücahid ve Katade'den gelen rivayetlerde Medine'de indiği söylenmiştir (Yazır, 2007, s. 493). Kur'an-ı Kerim'in 76'ncı suresi olup, 31 ayetten oluşmaktadır.

Konusu: Genel olarak insanın yaratılışının ve nimetlere mazhar olmasının hikmetini kavramaya, Allah'ı tanıyı O'nun verdiklerine şükretmeye, azabından sakınmaya ve ahiretteki değerli nimetleri elde etmenin şartlarını gerçekleştirmeye bir çağrı niteliğindeki sure, muhtevası bakımından yeniden dirilmenin kesinliğini vurgulayan ve ahiret hallerini özetleyen bir önceki Kıyâme Suresi'nin tamamlayıcısı gibidir (Yaşaroğlu, 2000, s. 331).

13- Zümer Suresi: İç mekânda zemin ana mezar odasının güney kemerin yazı kuşağında ve cenazelik katında bulunan sanduka üzerinde bulunmaktadır.

Zümer Suresi Mekke'de inmiştir. Kur'an-ı Kerim'in 39'uncu suresi olup, 75 ayetten oluşmaktadır (Yazır, 2007, s. 535). Surenin adı 73'üncü ve 75'inci ayetlerde geçmektedir.

Konusu: Zümer Suresi'nde Kur'an'ın vahiy ürünü olduğu çeşitli ayetlerde vurgulanmakta, şirk inancı reddedilip tevhid inancı telkin edilmekte, uyarı ve müjdeleme üslûbuyla ahiret âlemi hatırlatılmakta, cennet ve cehennem hayatı tasvir edilmektedir. Bu arada tabiatın yaratılışı ve işleyişiyle insanın psikolojik özelliklerine değinilmekte ve onun dinî gerçeklere ulaşmasına zemin hazırlanmaktadır. Surede bu konular sistematik biçimde değil diğer birçok surede olduğu gibi- dünya hayatına paralel olarak karışık bir şekilde yer almaktadır. Surenin temel konusu Allah ve ahiret inancıdır. Bu çerçevede hiçbir şeyin Allah'a ortak ve denk tutulamayacağı, O'nun mutlak ve eşsiz yaratıcı olduğu, bu sebeple insanın her durumda O'na yönelip bağlanması gerektiği belirtilmekte; bu şekilde inanan 
ve yaşayanların ulaşacağı ahiret nimetlerine ve cennet hayatına dair bilgi verilmekte; inkârcıların olumsuz duygu ve davranışları değerlendirilmekte, bunların kötü sonuçları üzerinde durulmaktadır (Topaloğlu, 2013, s. 57172).

14- Fussilet Suresi: Zemin katta bulunan Mümtaz Mahal'e ait sanduka üzerinde bulunmaktadır.

Fussilet Suresi; Secde Suresi, Ha Mim Secde Suresi, Mesabih Suresi, Akvat Suresi dahi denilen bu sure de Mekke'de inmiștir (Yazır, 2007, s. 601). Kur'an-ı Kerim'in 41'inci suresi olup, sure 54 ayetten oluşmaktadır. Sure ismini 3'üncü ayette geçen ve ayrıntıları ile açıklandı anlamına gelen "fussilet" kelimesinden almaktadır.

Konusu: Kur'an'ın, rahmân ve rahîm olan Allah'ın katından indirilmiş bir kitap olduğunu belirten açıklamayla başlayan surede, Mü'min Suresi'nde olduğu gibi büyük ölçüde iman konuları işlenmiş ve bu bakımdan Mekke putperestlerinin durumu; Peygamber, Kur'an ve İslâm karşısındaki inkârcl, inatçı ve baskıcı tutumları, özellikle Kur'an karşısındaki peşin hükümleri ve onun sesini boğma gayretleri, nihayet bütün bu davranışlarıyla nasıl bir akıbeti hak ettikleri üzerinde durulmuş; yer yer geçmişteki bazı kavimlerin, kendi dinleri ve peygamberleri karşısındaki haksız tavırlarıyla bu yüzden başlarına gelen felâketlere dair uyarıcı mahiyette kısa bilgiler verilmiştir. Surenin özellikle 30'uncu ila 36'ncı ayetlerinde Kur'an'ın, Allah'a iman temeline dayanan, daima dürüst olunmasını, insanlar arasında sıcak dostluğa, barış ve uzlaşmaya dayalı ilişkiler kurulmasını amaçlayan ahlâk öğretisi özetlenmiştir (Işık, 1996, s. 228-29).

15- Mü'min Suresi: Zemin katta bulunan sanduka üzerinde bulunmaktadır.

Mü'min Suresi Mekke'de inmiştir. Kur'an-ı Kerim'in 40'ıncı suresi olup, 85 ayetten oluşmaktadır (Yazır, 2007, s. 563). Sure ismini 28'inci ayetinde geçen ve inanan iman eden kimse anlamına gelen "mü'min" kelimesinden almaktadır.

Konusu: Mü'min Suresi'nde ağırlıklı olarak “Allah'ın ayetlerini tartışmaya kalkışanlardan, bu ayetlere karşı mücadele verenlerden söz edilmekte; genellikle Mekke putperestlerinin aristokrat tabakasından oluşan bu kesimin karakteri, genel tutumları ve amaçlarıyla görecekleri cezalar üzerinde durulmaktadır. Sure, Allah'ın rahmetinin ve ilminin genişliği, kudretinin sınırsızlığı; ilâhî hakikatleri yalanlamaya kalkışanların cezaları ve pişmanlıkları, uhrevî yargılamanın adaletli oluşu gibi konulara dair açıklamalarla başlar. Hz. Mûsâ ile Firavun ve onu izleyenler arasında geçen 
mücadeleye değinilirken Mûsâ'nın dinine gizlice inanmış bir müminin inkârcılara yönelttiği anlamlı ve yararlı uyarılara yer verilir. Allah'tan başka ilâh bulunmadığı ve O'ndan başkası için yapılan ibadetlerin geçersiz olduğu, Allah'a şükretmekten yüz çevirenlerin bu yanlıştan dönmelerini sağlamak üzere onlara ilâhî nimetlerin hatırlatılması, öldükten sonra tekrar dirilmenin mümkün olduğunun kanıtlanması ve bu konuda insanların uyarılması, Allâhü Teâlâ'nın resulünü destekleyeceğine dair vaadi surenin başlıca konularındandır. Sure, ellerinde firsat varken gerçeği görüp $\mathrm{Hz}$. Peygamber'in getirdiği açık seçik gerçekleri kabul edecekleri yerde, kendi temelsiz bilgilerine güvenerek kibre kapılıp inkâr yolunu seçenlerin ilâhî ceza ile yüz yüze geldiklerinde inanmalarının artık kendilerine fayda vermeyeceği uyarısında bulunan açıklamalarla son bulmaktadır (Yaşaroğlu, 2006, s. 558-59).

16- Mutaffifin Suresi: Zemin katta bulunan sanduka üzerinde bulunmaktadır.

Tatfif Suresi de denile bu sure Mekke döneminde inen son suredir. Hz. Peygamber (s.a.v.) Medine'ye geldiği zaman Medinelilerin ölçekleri kötü olduğundan dolayı düzeltilmesi için Medine'de ilk inen sure olduğu da rivayet edilmiştir. Medine'ye varmadan önce Mekke ile Medine arasında indiği de söylenmiştir ki, o da Mekke'de inmiş demektir (Yazır, 2007, s. 61). Kur'an-1 Kerim'in 83'üncü suresidir ve 36 ayetten oluşmaktadır.

Konusu: Surede ölçü ve tartıda dürüstlükten sapanlar eleştirildikten sonra ahireti ve uhrevî sorumluluğu inkâr eden günahkârların ahirette göreceği cezalar ve iyilerin nâil olacağı mükâfatlar özetlenmekte; dünyada müminlerle alay eden inkârcıların ahirette asıl kendilerinin gülünç duruma düşecekleri anlatılmaktadır (Yaşaroğlu, 2006, s. 371-72).

17- Bakara Suresi: Zemin katta bulunan sanduka üzerinde bulunmaktadır. Bakara Suresi Medine döneminde Peygamberimizin (s.a.v.) Medine'ye hicret etmelerinden sonra ilk inen suredir. Ancak Medine'de ilk inmeye başlayan ve en sonra tamamlanan suredir. Kur'an-1 Kerim'in 2'nci ve 3'üncü suresidir. Sure 286 ayetten oluşmaktadır (Yazır, 2007, s. 181).

Konusu: Kur'an-ı Kerim'in kendine mahsus tertip ve üslûbu içinde şu ana konuları ihtiva etmektedir: İslâm'ın getirdiği inanç, ibadet ve hayat düzeniyle ilgili temel bilgiler; münafıklar, Allah'ın varlığını ve birliğini gösteren deliller, insanın yaratılışı, kabiliyetleri, imtihanı; İsrâiloğulları tarihinin önemli kesitleri, kâmil bir din olan İslâm'ın, daha önceki dinlerin evrensel kısmını ihtiva ettiği, buna karşılık onların değişmesi, ıslah edilmesi, düzeltilmesi gereken- hükümlerini de ıslah ettiği; Hz. İbrâhim kıssası, 
Kâbe'nin yapılışı ve kıble oluşu; yiyecekler, kısas, vasiyet, oruç, savaş, hac, nikâh, boşama, dulluk, yetimlik, şarap, kumar, faiz, akidlerin yazılması, din ve vicdan hürriyeti, Allah-kul ilişkisi, örnek dualar vb. hususlarla ilgili hükümler ve irşadlar. Bakara Suresi daha ziyade Fâtiha'nın, "doğru yolu bulanlarla ondan sapanlar"a işaret eden kısmının, örnekler ve tarihî vâkıalarla açıklanması gibidir (Işık, 1991, s. 526-29).

18- Haşr Suresi: Zemin katta ve cenazelik katında bulunan sanduka üzerinde bulunmaktadır.

Haşr Suresi Medine'de inmiştir. Bikai, bu sureye "Beni Nadir" suresi denildiğini de nakletmiştir (Yazır, 2007, s. 521). Kur'an-ı Kerim'in 59 'uncu suresidir. Sure 24 ayetten oluşmaktadır.

Konusu: Özellikle surenin ilk ayeti ile son üç ayetinde, bütün varlıkların Allah'ı eksikliklerden tenzih ettiği, O’nun birliği, yüceliği, ilminin sınırsızlığı, rahmet ve şefkatinin enginliği, irade ve gücünün mutlaklığı, eşsiz yaratıcı olduğu belirtilerek kalplere tevhid inancının, Allah sevgisi ve saygısının yerleștirilmesi hedeflenmektedir. 2'nci ila 10'uncu ayetlerde antlaşmalarını bozan bir Yahudi kabilesinin başına gelen sürgün felâketi örnek gösterilip bundan ibret alınması istenmekte ve Müslümanlara toplum olarak elde edilen imkânların paylaştırılması konusunda yol gösterilip ideal mümin tipiyle ilgili tasvirler yapılmaktadır. 11'inci ila 17'nci ayetlerde Müslüman göründükleri halde ahitlerini bozan Ehl-i Kitap’la gizli ilişkiler kurarak türlü entrikalar çeviren münafıkların ve yandaşlarının bazı zaaflarına değinilerek Müslümanlar hem bu tür davranışlardan sakındırılmakta hem de kendilerine moral verilmektedir. Müteakip ayetlerde her insanın yapması gereken nefis muhasebesinin ve ebedî hayat için hazırlıklı olunmasının önemine ve sonuçlarına dikkat çekilmekte; Kur'an'a muhatap olmanın ne büyük şeref olduğunu ama aynı zamanda ne büyük sorumluluk getirdiğini hatırlatan bir örnek verilmektedir (Işık, 1997, s. 424-26).

19- Ali İmran Suresi: Türbenin cenazelik katında bulunan sanduka üzerinde bulunmaktadır.

Ali İmran Suresi Medine'de inmiștir. Kur'an-ı Kerim' in 89'uncu suresidir ve 200 ayetten oluşmaktadır. Bu sureye "Eman", "Kenz", "Ma'niyye", "Mücadele", "İstiğfar" ve "Tayyibe" suresi de denilmektedir (Yazır, 2007, s. 317).

Konusu: Başlangıcında yüce Allah'ın "hay" ve "kayyûm" olduğu hatırlatılan ve Kur'an-ı Kerim'in önceki ilâhî kitapları onaylama özelliğinden söz edilen bu surede, vahye dayalı dinler arasındaki tekâmül ilişkisine işaret 
edilmekte, Allah katında yegâne geçerli dinin İslâm olduğu vurgulanmakta, İslâm'ın inanç esasları (özellikle ulûhiyyet ve nübüvvet) ile (bir ve takvâ gibi) bazı temel ahlâk kavramları üzerinde durulmakta, Mekke'deki kutsal evden (Kâbe) söz edilmekte, hac vecîbesine ve başka bazı amelî görevlere değinilmektedir (Işık, 1989, s. 307-309).

20- Mü'minun Suresi: Cenazelik katında bulunan sanduka üzerinde bulunmaktadır.

Mü'minun Suresi, Mekke'de inmiştir. Kur'an-1 Kerim' in 23'üncü suresidir ve sure 119 ayetten oluşmaktadır.

Konusu: Mü'minûn Suresi'nin öncelikli konusu inananların üstün nitelikleridir. Daha sonra her bir insanın anne karnındaki oluşum süreci, Hz. Nûh ve adı verilmeyen bir peygamber ile Mûsâ ve Hârûn hakkında ibretli bilgiler, tebliğlerinin ortak noktaları, peygamberlerin yolundan giden ümmetlerin ve onların yolundan sapan inkârcıların başlıca özellikleri, Mekke putperestlerinin, sorulduğunda Allah'ın yaratıcı gücünü kabul etmelerine rağmen O'na ortak koşmaları ve ahirete inanmamaları, bunların ahiretteki acıklı durumları, pişmanlıkları ve karşılık bulmayacak dilekleri hakkında açıklamalar yapılmaktadır. Sure, "Rabbim! Beni bağışla, bana merhamet et; sen merhametli olanların en üstünüsün!" mealindeki dua cümlesiyle son bulur (Yaşaroğlu, 2006, s. 560-61).

21- Şems Suresi: Caminin iç mekânda kemerdeki geniş yazı kuşağında sülüs hatla Şems Suresi bulunmaktadır.

"Ve'ş Şemsi" suresi de denilen Şem Suresi ittifakla Mekke'de inmiştir (Yazır, 2007, s. 251). Kur'an'ı Kerim'in 91'inci suresidir, 15 ayetten oluşmaktadır.

Konusu: Surede bazı önemli kozmik varlıklara ve olaylara yemin edilerek insan tabiatına hem iyilik hem kötülük eğilimlerinin verildiği bildirilmiş; bu eğilimlerini doğru kullanmayanların akıbetine örnek olmak üzere Semûd kavminin helâk edilişi anlatılmıştır (Yaşaroğlu, 2010, s. 51011).

22- İhlas Suresi: Caminin iç mekânda kemerdeki geniş yazı kuşağında bulunmaktadır.

İhlas Suresi Mekke'de inmiştir ve dört ayetten oluşmaktadır. İhlas ve "Kul hüvallahü ehad" en yaygın kullanılan isimleridir. "Tevhid Suresi", "Tefrid Suresi", "Tecrid Suresi", "Necat Suresi", "Velayet Suresi", Ma'rifet Suresi" de denilmiştir. Çünkü bu surenin içeriğini tam kavramakla Allah tanınmış olur (Yazır, 2007, s. 59). 
Konusu: Surede Allâhü Teâlâ'nın bazı sıfatları veciz bir şekilde ifade edilmiştir. Kur'an-ı Kerim'in bir din kitabı olduğu ve onun ayetlerinin Allah'ı doğru tanıtmayı ve O'na karşı kulluk görevlerini bildirmeyi hedeflediği dikkate alınınca İhlâs Suresi'nin bütün sürelerle ilişkisinin bulunduğu görülür. Meselâ Fâtiha Suresi'ndeki, "Biz ancak sana ibadet eder ve ancak senden yardım dileriz” mealindeki ayetle Allah'ın samed ismi arasında böyle bir iliş̧inin varlığı dikkat çekmektedir. İhlâs'tan sonra gelen Felak ve Nâs surelerinde ise insanlar, "samediyyet" diye ifade edilen Allah'ın büyük lütufkârlığından ve koruyuculuğundan istifade etmeye çağrılmaktadır. (Işıı, 2000, s. 537-38).

Yukarıda belirtilen sure ve ayetlerin dışında Tac Mahal Camisi'nde duvar yüzeylerinde ve mihrabın kemer köşeliklerinde "Ya Kâfi", "Allah", "Kelime-i Tevhid" ve "Kelime-i Şehadet" yazıları madalyonlar içerisinde yer almaktadır. Tac Mahal Türbesi'nin cenazelik katında Mümtaz Mahal'in ve Şah Cihan'ın sandukası üzerinde ise Esma-ül Hüsna (Allâhü Teâlâ'nın 99 ismi) bulunmaktadır

B-Tac Mahal'in Hat Süslemelerinin Yazı Stilleri: Babürlü döneminde nesih, sülüs, tuğra ve nestalik olmak üzere dört yazı stili kullanılmıştır (Rahman, 1987, s. 240). Hat süslemeleri oluşturan yazılar; Arapça ve Farsça yazılmıştır. Tac Mahal'in hat süslemelerinde özellikle türbesinde yoğun olarak sülüs yazı stili kullanılmış bunun yanında camisinde ve türbede bulunan sandukalar üzerinde nesih, nestalik ve tuğra yazı stili tercih edilmiştir. Tac Mahal'in hat süslemeleri Arap harfleri ile yazılmıştır. Tac Mahal'in hat süslemelerini oluşturan hattat Emanet Han imzasını ve tarih içeren bilgileri daha küçük ve Farsça yazmıştır.

Sülüs: Sözlükte "üçte bir" anlamına gelen sülüs, hat sanatında genellikle ağzı $3 \mathrm{~mm}$. genişliğindeki kamış kalemle yazılan çok işlenmiş en eski yazı çeşididir. Kûfî gibi sülüs yazı da İslâm yazılarının kaynağı (ümmü'lhat) olarak kabul edilmiş, hat öğrenimine sülüs yazı ile başlamak gelenek halini almıştır. "Kalem-i sülüs" diye de adlandırılan sülüsün, tomar kaleminin üçte biri kalınlığında veya sülüs harflerinin üçte iki kısmında düzlük, üçte bir kısmında yuvarlaklık olması sebebiyle bu adı aldığı ileri sürülür (Serin, 2010, s. 128).

Babürlü dönemi mimari eserlerinde yaygın olarak sülüs yazı kullanımının tercih edilmesi dikkat çekicidir. Tac Mahal'in türbesi, camisi ve anıtsal giriş bina düzenlemesinde yer alan yazıtlar sülüs hatla oluşturulmuştur. Bununla birlikte Delhi şehrindeki Babürlü dönemine ait özellikle hat süslemeleri ile dikkat çeken Ategeh Han Türbesi'nin bütün diş 
cephesini çevreleyen yazı kuşağı ve sandukalarında bulunan yazıların sülüs yazı stiline sahip olduğu görülmektedir. Babürlü dönemine ait diğer türbe örneklerinden Ekber Şah Türbesi'nin yazı süslemeleri, İtimadu'd-Devle Türbesi'nin yazı süslemeleri ve Çinili Ravza Türbesi'nin yazı süslemeleri sülüs yazı sitili ile yazılmıştır.

Nesih: Sözlükte "hükmünü ortadan kaldırmak, bir eseri istinsah etmek" gibi anlamlara gelen nesh kelimesi, hat sanatında özellikle kitap istinsahında ve basma eserlerde yaygın biçimde kullanılan bir yazı çeşididir. Aynı kökten gelen nessâh kelimesinin nessâhân-ı hattâtîn (nesih yazanlar) şeklinde kaynaklarda yer aldığı görülmektedir (Âlî, s. 24) (Derman, 2007, s. 1).

Nestalik: Ta'lik yazının okuma ve yazma güçlüklerinin, harf bünyelerinde görülen aşırı, girift ve karmaşık çizgilerin ortadan kaldırılıp nesih yazısı ile birleşmesinden doğan bir yazı çeşididir. Önceleri nesh ü ta'lîk, daha sonra nesh-i ta'lîk şeklinde yazılırken nesta'lik olarak yaygınlaşmıştır. Nesh-i ta'lîk, "ta'likin hükmünü ortadan kaldırma" anlamını taşıdığı için bu adı aldığını ileri sürenler de vardır. İranlılar bu yazıya nesta'lik, Araplar hattı Fârisî, Türkler ise ta'lik adını verirler, ancak hat literatüründe nesta'lik terimi kullanılmıştır. Kırlangıçların yayvan uçuşunu andıran görünüşüyle ince, zarif, sade ve mütenasip olan nesta'lik "İslâm yazılarının gelini" (arûs-ı hutût) diye anılmıştır (Alparslan, 2007, s. 11).

Babürlü dönemi türbe örneklerine bakıldığında nestalik yazı stilinin ilk olarak Ekber Şah Türbesi bahçe güney giriş kapısı; bu bütünü sınırlayan ise tuğra-nestalik karakterleri kullanılarak beyaz mermerden kabartma olarak yazılmış bir kitabesi yer almaktadır. Kitabe hattat Abdul Hak Şirazi tarafından yazılmıştır (Edmund W. Smith, 1994) ve güney kapı boşluğunun batı kenarında (Hicri 1022) 1613 tarihi bulunmaktadır. Ekber Şah Türbesi dışında İtimadu'd-Devle Türbesi ve Tac Mahal Türbesi'nin bazı yazı süsleme programlarında bu yazı stili görülmektedir. Tac Mahal'de Mümtaz Mahal'in sandukaları üzerinde bulunan yazılar nestalik yazı stilinde oluşturulmuştur.

Tuğra: Ekber Şah döneminde kullanılmaya başlanan bu yazı stiline ilk olarak Fetehpur Sirki'de bulunan Selim Çisti türbesinde karşılaşılmaktadır (Rahman, 1987, s. 240). Daha sonra Sikandara'da bulunan Ekber Şah Türbesi'nin güney giriş kapısı üzerinde yer alan kitabeleri tuğra stilinde yazılmıştır. Tac Mahal Türbesi'nin hat süslemelerinde tuğra yazı stili sadece camisinde ve sandukalarında bulunmaktadır.

C-Tac Mahal ile İtimadu'd-Devle Türbesi'nin Hat Süslemelerinin Karşılaştırılması: Agra şehrinde bulunan İtimadu'd-Devle Türbesi (1622- 
28) ile Tac Mahal Türbesi (1632-43) Babürlü döneminin önemli anitsal eserlerindendir. Her şeyden önce bu iki yapı birbiri ardı ardına inşa edilmiştir. İtimadu'd-Devle Türbesi; Mümtaz Mahal'in dedesi için halası Nur Cihan Hatun tarafından babası Mirza Giyaz Bey adına yaptırılmıştır. Her iki yapının mimari, malzeme, teknik ve süsleme özellikleri oldukça benzerlik göstermektedir. Tac Mahal ve İtimadu'd-Devle Türbesi hat süslemeleri bakımından da yakın benzerlik göstermekte kullanılan yazı stili ve tercih edilen Kur'an-ı Kerim'den bazı sure ve ayetlerin aynı olması dikkat çekicidir. Hat süslemeleri Tac Mahal'de bahçe giriş kapısından itibaren görülmeye başlarken İtimadu'd-Devle Türbesi'nin giriş bina düzenlemelerinde hat süslemelere rastlanılmamıştır. Tac Mahal'de bütün dış cephede hat süslemelere rastlanırken, İtimadu'd-Devle Türbesi'nin güney cephesinde kitabe kısımları boş bırakılmıştır. İç mekânda alt katta kubbe kasnağında, üst katta duvar yüzeylerinde yine hat süslemelere yer verilmiştir. Tac Mahal'de türbenin dört cephesinde de taç kapıların kemerlerinde yazı kuşağında, türbenin iç mekanında duvar yüzeylerinde, kubbede, hem zemin hem de alt kattaki sandukalarda hat süslemelere yer verilirken; İtimadu'd-Devle Türbesi'nin güney cephe dışında diğer bütün cephelerinde giriş açıklığındaki kemerlerinde ve yan yüzlerinde kemerlerde alınlık kısmında hat süslemelere yer verildiği ayrıca iç mekanda alt katta kubbe kasnağında ve üst katta yer alan köşkte duvar yüzeylerinde hat süslemeler mevcutken hem alt hem de üst kattaki sandukalarda hat süslemelerin bulunmadığı yoğun bir şekilde bitkisel süslemelere yer yerildiği görülmektedir. Fakat her iki yapının arasındaki en ilginç ortak özellik, bazı Kuran bölümlerinin seçilmesindeki ve bunların neredeyse aynı mimari unsurlara yerleștirilmesindeki benzerliktir. Her iki yapıda El-Mülk ve El-Fetih sureleri ile bezenmiștir. El-Mülk Suresi, İtimadu'dDevle Türbesi'nin kubbe kasnağını, güney-doğu kemerini, üst yapı köşkünün içini süslemekte iken, Mülk Suresi; Tac Mahal'in ana mezar odasının kubbe kasnağı ile güneydoğu kemerini süslemektedir. Fetih Suresi ise Tac Mahal'in ana mezar odasını güney-doğu, doğu, kuzey-doğu, kuzey, kuzey-batı ve batı kemerleri boyunca dolaşırken, İtimadu'd-Devle Türbesi'nde niş ve kemer açıklıklarını çevreleyen dört dış duvarın etrafında batı, kuzey, doğu, güney yönünde dolaşmaktadır. El-Mülk Suresi ayrıca İtimadu'd-Devle ve Tac Mahal'den daha önce yapılmış olan Agra yakınlarındaki Sikandara'da bulunan Ekber Şah Türbesi'nin ana mezar odasına geçmeden, gösterişli giriş holünün duvar yüzeylerini süslediği görülmektedir.

Her iki türbenin de hat süslemeleri genel olarak sülüs yazı stili ile oluşturulmuştur. Tac Mahal'in hat süslemelerinde ayrıca nesih, nestalik ve 
tuğra yazı stilleri de kullanılmıştır. Her ikisinin de yazıt programı Arapça olup Tac Mahal'de Abdülhak Şirazi özel olarak belirtmek istediği bilgileri içeren alanlarda Farsça'yı tercih etmiştir. Kısacası her iki yapının yazıt programı içerik ve kompozisyon olarak benzerdir.

Tac Mahal'in yazıları hattat Abdülhak Şirazi tarafından işlenmiştir. Tac Mahal'in hat süslemelerini Abdülhak Şirazi ile birlikte birçok yardımcı hattatında çalıștığı bilinmektedir. Bunlardan birisi de Osmanlı tebaasından olduğu bilinen hattat Settar Han'dır (Beksaç, 2010, s. 39). İtimadu'd-Devle Türbesi'nin hat süslemeleri ise Abd El Nabi el-Kureyşi tarafından (Stefanovic, 2012, s. 30) işlenmiştir. Tac Mahal'in inşasının başlamasından sadece birkaç yll önce tamamlanmış olan İtimadu'd-Devlet Türbesi'ndeki Kuran ayetlerinin seçilmesinin Tac Mahal'i etkileyip etkilemediğini tam olarak söylemek mümkün değildir. İtimadu'd-Devle Türbesi'nden sorumlu olan Abd Al-Nabi El-Kureyşi, atölyesi Tac Mahal'den sorumlu olan dönemin ünlü sanatçllarından Amanat Han, hatta saltanatı sırasında İtimat-ud-Devle inşa edilen Cihangir'in sarayının baş hattatı olan Mir Abd Allah Mushkin Qalam gibi sanatsal eserlerini imzalayan hattatlar arasinda sanatsal ve sosyal bir ilişki ve etki olup olmadığı şimdiye kadar bulunamamıştır (Stefanovic, 2012, s. 23).

İtimadu'd-Devle Türbesi gibi Tac Mahal'de de Babürlü dönemi ana malzemesi olan kırmızı kumtaşının aksine beyaz mermer kullanımı tercih edilmiştir. İtimadu'd-Devle Türbesi'nin hat süslemeleri beyaz mermer malzemeden oluşturulmuşken; Tac Mahal'in hat süslemeleri beyaz mermer zemin üzerine siyah renkli oniks taşı kullanılarak oluşturulmuştur. Tac Mahal'in hat süslemeleri beyaz mermer üzerine kakma tekniği ile siyah renkte oniks taşından oluşturulmuştur. İtimadu'd Devle'de ise beyaz mermer oyularak hat süslemeler oluşturulmuştur.

Babürlü dönemi hat süslemeler için Tac Mahal Türbesi önemli bir örnek teşkil etmesine rağmen İtimadu'd-Devle Türbesi'nin hat süslemeleri hem teknik hem de estetik açıdan hat sanatı için yazının aynı görsel etkisini yansıtmaz. Tac Mahal'in hat süslemeleri ilk bakışta dikkatleri üzerine çekerken, çok dikkat edilmediği sürece İtimadu'd-Devle de yer alan hat süslemeleri fark etmek dahi oldukça güçtür. Tac Mahal Türbesi ile İtimadu'dDevle Türbesi arasında benzerlikler yukarıda da bahsedildiği gibi oldukça önemli boyuttadır. Ayrıca her iki türbenin mimarlık ve süsleme unsurlarının ilkeleri, teknikleri ve stil özellikleri dönemdeki yeniliklerin seviyesini, gelişim ve değişim seyrini açıkça yansıtmaları açısından önem taşımaktadır. 


\section{Sonuç}

Tac Mahal'in süslemelerini; bitkisel motifler, geometrik desenler ve yazı oluşturmaktadır. Tac Mahal'in hat süslemeleri; Darvaza-i Ravza giriş kapısının kemerinde yazı kuşağında, türbenin dört cephesinde yer alan taç kapısının yazı kuşağında, kubbe kasnağında, iç mekânda eyvanların yüzeyinde, üst katta ve alt katta bulunan sandukalarında karşımıza çıkmaktadır. Mihman hanesinde Kuran ayetlerinin olmaması aslında burasının gelen misafirler için dinlenme konaklama olması ve bu nedenle saygıdan dolayı Kur'an ayetlerinin burada bilinçli bir şekilde yer almadığı kanısını güçlendirmektedir.

Tac Mahal'de Kur'an-ı Kerim'den toplam 22 adet sure bulunmaktadır. Bu sureler: Fecr Suresi, Duha Suresi, İnşirah Suresi, Tin Suresi, Yasin Suresi, Tekvir Suresi, İnfitar Suresi, İnşikak Suresi, Beyyine Suresi, Mülk Suresi, Fetih Suresi, İnsan Suresi, Zumer Suresi, Fussilet Suresi, Mü'min Suresi, Mutaffifin Suresi, Bakara Suresi, Haşr Suresi, Ali İmran Suresi, Mü'minun Suresi, Şems Suresi ve İhlas Suresi'dir. Tac Mahal'de 25 yazit bulunmakta ve bu yazıtlardan bazılarında Zumer, Fussilet ve Haşr iki kez tekrarlanmış, diğer sureler sadece bir kez yazılmış olup sureler tamamıla işlenmiştir. Dört cephede yer alan Yasin Suresi en geniş yeri kaplarken iç mekânda kemerin üst kuşağında bulunan Mülk Suresi ise ikinci en uzun ayetleri içermektedir. Camide yer alan İhlas Suresi ise en kısa ayetleri içermektedir.

Tac Mahal'de yer alan sureler genel olarak ahiret, ölüm, cennet kıyamet günü, inananlara müjde gibi konuların ağırlıklı olarak yer aldığı surelerdir. Tac Mahal'de diğer örneklerde olduğu gibi baniyi ve ölen kişiyi öven herhangi bir methiyeye rastlanılmamıştır. Aynı dönemde Şah Cihan'ın kızı tarafından babası adına yaptırılan Agra'daki Mescid Camisi'nde Şah Cihan'ı ve hükümdarlığını öven birçok yazı bulunmaktadır (Begley, 197879). Bu da baninin türbede kendi özel tercihi olduğunu, faniliği ön planda tutarak övgüden uzak mutlak varlık sahibine teslim oluşunu göstermektedir. Ayrıca tercih edilen sure ve ayetler; dünya hayatının faniliğini ve ahiret gününü hatırlatan bununla birlikte Allah-u Teala'nın emir ve yasaklarına itaat edenlerin kurtuluşa ereceği ve cennetle müjdeleneceklerini vaat eden ayetlerin seçimi nedeniyle bu yazıtların daha çok türbeye gelen ziyaretçileri hedef aldığı görülmektedir. Ayrıca Babürlü türbeleri genel olarak cennetle ilişkilendirilmektedir. Babürlü bahçeleri Kur'an-ı Kerim'de bahsedilen cennet bahçeleri tasvirlerine göre tasarlanmış her bir türbe yapısına anıtsal giriş kapıları ile girilmesi de adeta cennet kapılarını anımsatmasına sebep olmuştur. Ayrıca türbelerde bulunan yazıtlardaki ayetlerin ahiret hayatı ve 
cennetle ilişkili olması da bu konuyu güçlendirmekte olup özellikle Tac Mahal'in Darvaza-i-Ravza kapısı üzerinde Fecr Suresi'nin son ayetinin "Cennetime gir" şeklinde yer alması bu konuya da doğrular şekildedir.

Tac Mahal'in hat süslemeleri, hattat Emanet Han Şirazi tarafından işlenmiştir. Hat süslemeler, beyaz mermer üzerine siyah renkte oniks taşı ile kakma tekniği kullanılarak oluşturulmuştur. Tac Mahal'in hat süslemeleri; Arapça yazılmıştır ve genel olarak sülüs yazı stili kullanılmıştır. Ayrıca Mümtaz Mahal'in mezar sandukasında nesih yazı stili kullanılırken, Şah Cihan'ın mezar sandukası üzerinde nestalik yazı stili kullanılmış aynı zamanda cami mihrabında sülüs yazı stili yanında tuğra yazı stili de kullanılmıştır.

Sonuç olarak türbede bulunan hat süslemeler hem estetik hem de içerik olarak yapının derinlik kazanmasını sağlamıştır. Yapıda yer alan ayetlerin bilinçli seçimi buranın ebedi istirahat yeri olması sebebiyle cennetle ilişkilendirilen ayetlere sık sık yer verilmesi Babürlü türbelerinin bahçelerinin cennet bahçelerine anıtsal mezarlarının ise cennet mekanlarına benzetildiği fikrini güçlendirmektedir. Hat süslemelerdeki geometrik düzen ve simetri estetik anlayışını gözler önüne sermekte iken Kur'an-ı Kerim'deki surelerin seçimi anlamsal olarak verilmek istenen mesajın önemini de vurgulamaktadır. Yazıtlar, Tac Mahal'in dikkat çekici süsleme programının önemli bir parçasını teşkil etmektedir. Tac Mahal'in yazıt programı estetik olarak görsel zenginliğini arttırmasının yanında içeriğindeki anlamsal derinlik bu ayetlerin gelişi güzel bir biçimde seçilmediğini göstermektedir. Tac Mahal'in hat süslemeleri türbenin, sembolik anlamının da aslında önemli bir ifadesidir.

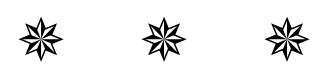

\section{KAYNAKÇA}

ALPARSLAN, A. (2007). Nestalik. TDV İslam Ansiklopedisi, 11-15.

BEGLEY, W. E. (1978-79). Amānat Khān And The Callıgraphy On The Tāj Mahal. Franz Steiner Verlag, 5-60.

BEKSAÇ, E. (2010). Tac Mahal. TDV İslam Ansiklopedisi, 39, 337-339. İstanbul.

BİRIŞIK, A. (2012). Tin Suresi. TDV İslam Ansiklopedisi, 41, 189-190. İstanbul: Test Yayını.

DEMIRIZ, Y. (1979). Osmanlı Mimarisi'nde Süsleme I. İstanbul: Kültür Bakanlığı.

DEMIRIZ, Y. (1979). Osmanlı Mimarisi'nde Süsleme I. İstanbul: Kültür 
Bakanlığı.

DERMAN, M. (2007). Nesih. TDV İslam Ansiklopedisi, 1-3.

Diyanet Isşleri Başkanlığı. (2020, Nisan 26). Fetih Suresi: https://kuran.diyanet.gov.tr/tefsir/sure/36-yasin-suresi adresinden alındı

EDMUND, W., SMITH, M. (1994). Akbar's Tomb, Sikandarah. New Delhi: Published By The Director General Archaeological Survey of India .

ISLAM, A. (2013). The Taj: An Architectural Marvel or an Epitome of Love? Australian Journal of Basic and Applied Sciences, 367-374.

Işık, E. (1989). Ali İmran Suresi. TDV İslam Ansiklopedisi, 2, 307-309. İstanbul: Test Yayını.

IŞIK, E. (1991). Bakara Suresi. TDV İslam Ansiklopedisi, 4, 526-29. İstanbul: Test Yayını.

IŞIK, E. (1992). Beyyine Suresi. TDV İslam Ansiklopedisi, 6, 98-99. İstanbul: Test Yayını.

IŞIK, E. (1994). Duha Suresi. TDV İslam Ansiklopedisi, 9, 546. İstanbul: Test Yayını.

IŞIK, E. (1995). Fecr Suresi. TDV İslam Ansiklopedisi, 12, 290-91. İstanbul: Test Yayını.

IŞIK, E. (1996). Fussilet Suresi. TDV İslam Ansiklopedisi, 13, 228-29. İstanbul: Test Yayını.

IŞIK, E. (1997). Haşr Suresi. TDV İslam Ansiklopedisi, 16, 424-26. İstanbul: Test Yayını.

IŞIK, E. (2000). İhlas Suresi. TDV İslam Ansiklopedisi, 21, 537-38. İstanbul: Test Yayını.

KARAÇA $\breve{G}$, A. (2002). Beylikler Devri Mimarisinde Alçı Süslemeler. Doktora Tezi. Konya.

KOCH, E. (2005). The Taj Mahal: Architecture, Symbolism, and Urban Significance. In Muqarnas: An Annual on the Visual Culture of the Islamic World, XXII, 127-149.

RAHMAN, M. (1987). Mughal Calligraphy, Vol. 26, No. 3 (Autumn). Islamc Studies, 237-246.

SERIN, M. (2010). Sülüs. TDV İslam Ansiklopedisi, 38, 128-130.

STEFANOVIC, A. (2012, Mayıs). The Tomb of I'timad ud Daula at Agra: Architecture, Decoration and Inscriptional Program. Master of Thesis. 
Belgrad: University of Belgrade.

TOPALOĞLU, B. (2011). Tekvir Suresi. TDV İslam Ansiklopedisi, 40, 390-91. İstanbul: Test Yayını.

TOPALOĞLU, B. (2013). Yasin Suresi. TDV İslam Ansiklopedisi, 43, 340-41. İstanbul: Test Yayını.

TOPALOĞLU, B. (2013). Zümer Suresi. TDV İslam Ansiklopedisi, 44, 571-72. İstanbul: Test Yayını.

YAŞAROĞLU, M. K. (2000). İnfitar Suresi. TDV İslam Ansiklopedisi, 22, 294. İstanbul: Test Yayını.

YAŞAROĞLU, M. K. (2000). İnsan Suresi. TDV İslam Ansiklopedisi, 22, 331-332. İstanbul: Test Yayını.

YAŞAROĞLU, M. K. (2000). İnşikak Suresi. TDV İslam Ansiklopedisi, 22, 343. İstanbul: Test Yayını.

YAŞAROĞLU, M. K. (2000). İnşirah Suresi. TDV İslam Ansiklopedisi, 22, 34546. İstanbul: Test Yayını.

YAŞAROĞLU, M. K. (2006). Muaffifin Suresi. TDV İslam Ansiklopedisi, 31, 37172. İstanbul: Test Yayını.

YAŞAROĞLU, M. K. (2006). Mülk Suresi. TDV İslam Ansiklopedisi, 31, 542. İstanbul: Test Yayını.

YAŞAROĞLU, M. K. (2006). Mü'min Suresi. TDV İslam Ansiklopedisi, 31, 55859. İstanbul: Test Yayını.

YAŞAROĞLU, M. K. (2006). Mü'minun Suresi. TDV İslam Ansiklopedisi, 31, 560-61. İstanbul: Test Yayını.

YAŞAROĞLU, M. K. (2010). Şems Suresi. TDV İslam Ansiklopedisi, 38, 510-11. İstanbul: Test Yayını.

YAZIR, E. M. (2007). Hak Dini Kur'an Dili. İstanbul: Zehraveyn.

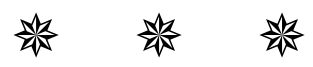




\title{
AN EVALUATION ON THE TAJ MAHAL'S CALLIGRAPHIC ORNAMENTS AND THE SURAHS AND VERSES IN ITS INSCRIPTIONS
}

\author{
(1) Fadime ÖZLER ${ }^{\mathrm{a}}$
}

\section{Extended Abstract}

The Taj Mahal, one of the most monumental mausoleums in the history of the world's architecture, constitutes a big building complex with its tomb, mosque and guest house in a char bagh garden on the south bank of the Yamuna River in the Agra city of India. Shah Jahan, the founder of the construction and the fifth ruler of Mughal State, built the mausoleum for his wife Mumtaz Mahal between the years of $1631-1654$, and when he died in 1666, he was also buried next to his wife. The Taj Mahal is an important construction with both its monumental architecture and its decorations. The decorations of the Taj Mahal include floral motifs, geometrical ornaments and calligraphic ornaments. The inscriptions, which constitute the calligraphic ornaments of the Taj Mahal, are an important part of the decoration pattern of the Taj Mahal. The calligraphic ornaments of the Taj Mahal are on the Darwaza-i Rauza (monumental south gate design), the mosque and the tomb. On the Darwaza-i Rauza, they are on the inscription line of the crown gate arch on the south and north. In the mausoleum, on the outer walls, the inscriptions are on the inscription lines of both interior and exterior arches of the iwan-formed crown gates at four directions. On the interior walls, the inscriptions are on the inscription lines of the arches, upper inscription lines surrounding the whole place over these arches, on the ground floor of the tomb, and on the actual tombs of Mumtaz Mahal and Shah Jahan downstairs. The inscriptions are on the inscription line surrounding the mihrab arch and in the medallions on the corners of the arches in the mosque. The calligraphic ornaments in the Taj Mahal are written in Arabic; they are in thuluth, naskh, nasta'liq and tughra style, and includes passages from the Quran. The calligraphic ornaments of the Taj Mahal were made by

a Res. Asst. Ph.D., Erciyes University, fadimeozler@gmail.com 
Amanat Khan Shirazi (Abd al-Haqq Shirazi) (Koch, 2005, p. 145). His signature as "Humble Amanat Khan Shirazi" is written in the central hall in the tomb, on the inscription line of the first arch on the left inside and on the upper inscription line surrounding the whole place. The calligraphy decorations of the Taj Mahal were formed by using the technique of inlaid with onyx stone with black color on white marble. There are twenty-two Surahs from the Quran in the Taj Mahal. These Suras are: Sura Fajr, Sura Dhuha, Sura Sharh, Sura Teen, Sura Yaseen, Sura Takweer, Sura Infitar, Sura Inshiqaaq, Sura Bayyinahh, Sura Mulk, Sura Fath, Sura Insaan, Sura Zumar, Sura Fussilat, Sura Mu'min(Ghafır), Sura Mutaffifeen, Sura Baqarah, Sura Hashr, Sura Al Imran, Sura Mu'minun, Sura Shams and Surah Ikhlaas. There are twenty-five inscriptions in the Taj Mahal, and some of these inscriptions are Zumar, Fussilat and Hashr. They are repeated twice. The other Suras are written only once and the Suras are fully engraved. Sura Yaseen, which is located on four fronts, occupies the widest place. Sura Mulk, which is located on the upper belt of the arch in the interior, contains the second longest verses. The Suras in the Taj Mahal are mostly about afterlife, death, heaven, Domesday, and the good news to the believers. There is no encomia in Taj Mahal that praises the deceased person as in other examples. The Masjid Mosque in Agra, which is built by Shah Jahan's daughter in the name of his father during the same period, has many writings praising Shah Jahan and his reign. (Begley, 1978-79). This shows that constituent wants to reflect his own special choice in the tomb and that he is surrendered to the absolute owner of being away from praise by keeping mortality in the foreground. In addition, the preferred Sura and verses remind that the mortality of the life of this world and timeless existence. Nevertheless, it is seen that these inscriptions mostly targeted visitors to the tomb due to the selection of the verses that promise that those who obey the commands and prohibitions of Allah-u Teala will be liberated and heralded with heaven.

The Taj Mahal has been handled in many ways by many researchers to this day and will undoubtedly continue to be handled from now on. Within the scope of the research, information on the places in the Taj Mahal on which calligraphic ornaments are made, calligraphy styles, what surahs from the Quran constituting these ornaments are and their contents will be tried to be given.

Keywords: History of Turkish-Islamic Arts, The Taj Mahal, Abd al-Haqq Shirazi, Calligraphic Ornament, Verse, Thuluth.

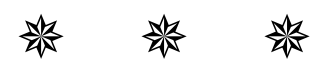

